\title{
Effect of nutrient amendments on bacterioplankton production, community structure, and DOC utilization in the northwestern Sargasso Sea
}

\author{
Craig A. Carlson ${ }^{1,2, *}$, Stephen J. Giovannoni ${ }^{3}$, Dennis A. Hansell ${ }^{1,4}$, \\ Stuart J. Goldberg ${ }^{1,2}$, Rachel Parsons ${ }^{1}$, Mark P. Otero ${ }^{1,2}$, Kevin Vergin ${ }^{3}$, \\ Benjamin R. Wheeler ${ }^{5}$
}

\author{
${ }^{1}$ Bermuda Biological Station for Research, Ferry Reach, St. George's, GEO1, Bermuda \\ ${ }^{2}$ Department of Ecology, Evolution, and Marine Biology, University of California, Santa Barbara, California 93106-9610, USA \\ ${ }^{3}$ Department of Microbiology, Oregon State University, Corvallis, Oregon 97331, USA \\ ${ }^{4}$ University of Miami Rosenstiel School of Marine and Atmospheric Science, Miami, Florida 33149, USA \\ ${ }^{5}$ Graduate College of Marine Studies, University of Delaware, Lewes, Delaware 19958, USA
}

\begin{abstract}
Bacterial abundance, DOC concentrations, and bacterioplankton community structure (using PCR-based techniques) were measured in 5 seawater culture experiments conducted near the Bermuda Atlantic Time-series Study (BATS) site in the northwestern Sargasso Sea. Cultures were amended with inorganic and organic nutrients, alone or in combination, to test the existence of the 'malfunctioning microbial loop' during late spring and summer at BATS. Objectives of the study were to determine whether (1) alleviating grazing pressure and inorganic nutrient limitation stimulated DOC remineralization by bacterioplankton; (2) a combination of organic and inorganic nutrients affect bacterial production and utilization of seasonally accumulated $\mathrm{DOC}_{\text {; }}$ and (3) shifts in bacterioplankton community structure are associated with nutrient amendment and DOC utilization. In unamended cultures natural assemblages of surface bacterioplankton did not utilize detectable amounts of naturally occurring 'semi-labile' DOC over time-scales of days to weeks. Neither bacterial production nor utilization of DOC was enhanced with the addition of inorganic $\mathrm{N}$ or $\mathrm{P}$ (alone or in combination). Labile DOC amendments stimulated bacterial production and DOC utilization, even in the absence of measurable inorganic nutrients, indicating that the bacterioplankton assemblage was initially energy limited, but did not stimulate utilization of seasonally accumulated DOC. The combination of inorganic $\mathrm{N}$ and $\mathrm{P}$ with labile DOC enhanced both bacterial production and utilization of 'semi-labile' DOC. Changes in bacterioplankton community rDNA gene profiles were minor in the control and inorganic treatments; however, utilization of 'semi-labile' DOC in the organic plus inorganic nutrient treatments coincided with significant changes in bacterioplankton community structure. These data suggest that bacterioplankton community structure, as well as nutrient regime, may be important factors governing the utilization of recalcitrant DOC substrates in the northwestern Sargasso Sea.
\end{abstract}

KEY WORDS: Dissolved organic carbon $\cdot$ Nutrient limitation $\cdot 16 \mathrm{~S}$ rRNA $\cdot$ BATS Resale or republication not permitted without written consent of the publisher

\section{INTRODUCTION}

Net production of dissolved organic carbon (DOC) in the open sea is ultimately derived from the temporal and spatial uncoupling of in situ biological production and consumption processes. Sources of 'freshly pro-

*Email: carlson@lifesci.ucsb.edu duced' DOC include direct exudation from phytoplankton (Lancelot 1979, Goldman et al. 1992), zooplankton excretion and egestion (Lampert 1978, Nagata \& Kirchman 1992), particle hydrolysis (Smith et al. 1992) and cell lysis from viral infection (Proctor \& Fuhrman 1991, Fuhrman 1992). Removal of DOC via bacterioplankton uptake is the primary biological consumption process in the sea (Pomeroy 1974, Azam \& 
Hodson 1977, Azam et al. 1983). Net DOC production within the euphotic zone has been documented for a variety of oceanic sites (Duursma 1963, Parsons et al. 1970, Eberlein et al. 1985, Copin-Montégut \& Avril 1993, Carlson et al. 1994, Børsheim \& Myklestad 1997, Hansell \& Carlson, 1998b, Carlson et al. 2000, Hansell \& Carlson 2001). The subsequent vertical mixing of a portion of the accumulated DOC out of the surface waters can be a significant carbon export term in certain oceanic systems (Copin-Montégut \& Avril 1993, Carlson et al. 1994, Ducklow et al. 1995, Hansell \& Carlson 1998a, Hansell \& Carlson 2001). However, for DOC to play a role in carbon export, the temporal scale of the DOC turnover has to be greater than the timescale of physical mixing processes (Thingstad 1993, Carlson et al. 1998, Hansell \& Carlson 2002). Thus, factors that prevent rapid bacterial utilization of 'freshly produced' dissolved organic matter (DOM) can indirectly influence the magnitude of carbon export to the ocean's interior.

Thingstad \& Rassoulzadegan (1995) and Thingstad et al. (1997) hypothesized that in some ocean systems competition for limiting nutrients and grazing pressure would reduce bacterioplankton growth rate, biomass, and carbon demand to levels that would allow accumulation of biodegradable DOC during biologically productive seasons. This hypothesis, known as the 'malfunctioning microbial loop', is supported by several studies in which inorganic nitrogen $(\mathrm{N})$ or phosphorus (P) amendments stimulated bacterial production (Pomeroy et al. 1995, Cotner et al. 1997, Rivkin \& Anderson 1997, Thingstad et al. 1998) and DOC utilization (Zweifel et al. 1993, 1999). If found to be a general phenomenon, the 'malfunctioning microbial loop' could have significant implications for understanding organic carbon storage and subsequent export of DOC.

The northwestern Sargasso Sea displays seasonal dynamics in DOC accumulation and inorganic nutrient depletion that are consistent with the 'malfunctioning microbial loop' hypothesis. Studies conducted at the Bermuda Atlantic Time-series Study (BATS) site show that DOC stocks accumulate rapidly within the euphotic zone shortly after restratification of the water column and remain at elevated concentrations through the summer into early autumn (Carlson et al. 1994, Hansell \& Carlson 2001). Deep convective mixing results in a portion of the seasonally accumulated DOC to be mixed to depth $(>200 \mathrm{~m})$. After stratification, the exported DOC becomes trapped within the mesopelagic zone and is remineralized over the time scale of weeks to months (Carlson et al. 1994, Hansell \& Carlson 2001).

Cotner et al. (1997) and Rivkin \& Anderson (1997) proposed, based on bacterial responses measured in nutrient enrichment cultures, that a portion of the DOC build-up observed at BATS resulted from P limitation of bacterioplankton growth. Extremely low inorganic phosphorus concentrations in the surface waters (Wu et al. 2000) would appear to support this hypothesis. However, DOC was not measured in these studies; thus, it is unknown how the measured bacterial response affected the DOC concentration in their cultures or within the mixed layer at the time these studies were conducted. Other studies hypothesize that it is the more recalcitrant nature of DOC substrates that prevents rapid microbial remineralization, resulting in the accumulation of 'semi-labile' DOC (Legendre \& Le Fevre 1995, Carlson \& Ducklow 1996, Carlson et al. 1998, Cherrier et al. 1996, Søndergaard et al. 2000). 'Semi-labile' DOC is operationally defined as DOC that, because of its chemical composition, is utilized slowly and/or is unavailable to a significant fraction of the heterotrophic prokaryotes on time-scales of months to years (Kirchman et al. 1993, Carlson \& Ducklow 1995, Cherrier et al. 1996, Anderson \& Williams 1999, Carlson 2002).

Several studies have demonstrated that major bacterioplankton groups form highly stratified populations in the surface layer of the open ocean (Giovannoni et al. 1996, Gordon \& Giovannoni 1996, Field et al. 1997, Karner et al. 2001). Cottrell \& Kirchman (2000) found that the consumption of specific dissolved organic compounds differed among various phylogenetic groups of bacterioplankton. Thus, in addition to the nutrient regime, bacterioplankton community structure may play a role in seasonal patterns of DOC accumulation and remineralization.

In the present study, a matrix of inorganic and organic nutrient amendments was applied to a series of open ocean seawater cultures to test for the existence of the 'malfunctioning microbial loop' during the late spring and summer periods in the northwestern Sargasso Sea. These experiments were conducted during periods of moderate water column mixing (spring) and stratification (summer). For each experiment, changes in bacterial abundance and DOC concentrations were measured. In addition, changes in bacterioplankton community structure were evaluated in several experiments using polymerase chain reaction (PCR) techniques. The specific objectives of the study were to determine (1) if naturally occurring DOC substrates became available for remineralization by surface bacterial assemblages when grazing pressure and inorganic nutrient limitation were alleviated; (2) how the combination of organic and inorganic nutrients affected bacterial growth and the utilization of seasonally accumulated $\mathrm{DOC}_{\boldsymbol{i}}$ and (3) if shifts in bacterioplankton community structure were associated with nutrient amendment and utilization of seasonally accumulated DOC. 


\section{MATERIALS AND METHODS}

Study site and water collection. We present data generated from 5 seawater culture experiments conducted in the northwestern Sargasso Sea from 1997 to 1998. Water was collected from Hydrostation S $\left(32^{\circ} 10^{\prime} \mathrm{N}, 64^{\circ} 30^{\prime} \mathrm{W}\right)$ or the BATS site $\left(31^{\circ} 40^{\prime} \mathrm{N}\right.$, $64^{\circ} 10^{\prime} \mathrm{W}$ ), located 26 and $82 \mathrm{~km}$ southeast of the islands of Bermuda, respectively (Fig. 1). We had not observed any systematic variability in microbial biomass or production nor DOC concentrations between Hydrostation S and BATS (Carlson et al. 1996, Carlson \& Hansell unpubl. data); thus, we felt it was appropriate to use either sampling site as a representative of northwestern Sargasso Sea open ocean conditions. Water from 1 to $20 \mathrm{~m}$ was collected from the RV Weatherbird II via Niskin bottles equipped with epoxy coated springs, on a conductivity, temperature and depth (CTD) rosette. Upon recovery, seawater was transferred to pre-cleaned polycarbonate carboys. All carboys were washed with $5 \% \mathrm{HCl}$ and rinsed with copious amounts of Millipore Q-water (Milli-Q) and sample water prior to the initiation of each experiment.

Field data collected at the BATS site were used to provide context for the annual patterns of DOC. Sample collection and analysis are detailed in Hansell \& Carlson (2001). A broader assessment of the BATS data is presented in Steinberg et al. (2001).

Seawater cultures. The seawater culture techniques of Ammerman et al. (1984) were employed. Natural assemblages of bacterioplankton were incubated in grazer-reduced cultures and allowed to grow on naturally occurring substrates alone or in combination with nutrient enrichments. Seawater cultures were prepared by diluting whole (unfiltered) seawater by $70 \%$ with $0.2 \mu \mathrm{m}$ filtrate. Preparation of $0.2 \mu \mathrm{m}$ seawater began within a few hours of collection. Seawater was gravity-filtered directly from a Niskin or collection carboy, through an all-plastic filtration rig containing a $142 \mathrm{~mm}$ Costar Membra-Fil filter $(0.2 \mu \mathrm{m})$, into a polycarbonate carboy. The Costar Membra-Fil filters provide a high flow rate and therefore gentle filtration can be employed, reducing cell lysis (Carlson \& Ducklow 1996). Membra-Fil filters initially leach a measurable amount of DOC, so we flushed at least 21 of Milli-Q water and an additional $0.5 \mathrm{l}$ of sample water prior to collection of experimental filtrate (Carlson \& Ducklow 1996). For each experimental treatment $7 \mathrm{l}$ of $0.2 \mu \mathrm{m}$ filtrate was inoculated with $3 \mathrm{l}$ whole seawater collected from the same cast.

Preliminary experiments conducted in the Sargasso Sea showed that prefiltration of bacterial inoculum through a $0.8 \mu \mathrm{m}$ filter prior to inoculation reduced bacterial activity (as assessed by short term ${ }^{3} \mathrm{H}$-thymidine incorporation assays) by greater than $60 \%$ over the course of $36 \mathrm{~h}$ when compared to a whole water inoculum (data not shown). These data indicate that prefiltration of bacterial inoculum either eliminates a significant portion of the actively growing population or the stress introduced by filtration inactivates a portion of the growing bacteria. In order to minimize potential biases associated with prefiltration of inoculum we chose to use a whole water inoculum.

Cultures were placed into an environmental chamber and incubated in the dark at in situ temperatures (Table 1). Because these cultures include some photoautotrophic bacteria and pico-eukaryotes, they were incubated in the dark to prevent accumulation of autotrophic biomass. Samples for bacterial abundance, DOC concentrations and environmental DNA were drawn at regular intervals over a period of 4 to $7 \mathrm{~d}$. In later experiments, an additional DOC sample was collected 1 to 2 mo after the culture initiation to assess the affect of long-term incubations on DOC utilization.

Nutrient enrichment. Each experiment comprised an unamended control plus several treatments enriched with nitrogen $\left(\mathrm{NH}_{4} \mathrm{Cl}\right)$, phosphorus $\left(\mathrm{K}_{2} \mathrm{HPO}_{4}\right)$ and labile DOC (glucose). Glucose was chosen for the labile DOC enrichment because it is the most abundant dissolved free neutral sugar in oceanic systems, and because it is preferentially utilized relative to other free monosaccharides (Rich et al. 1996, Goldberg et al. 2000). Enrichments of $\mathrm{C}, \mathrm{N}$ or $\mathrm{P}$ were added individually or in combination with final concentrations of $10 \mu \mathrm{M} \mathrm{C}, 1 \mu \mathrm{M} \mathrm{N}$ and $0.1 \mu \mathrm{M}$ P (Table 1). Although the concentrations of inorganic nutrients are maintained at concentrations below colorimetric detection limits for most of the year, annual deep convective mixing (170 to $>300 \mathrm{~m}$ ) and mesoscale eddy pumping can entrain measurable con-

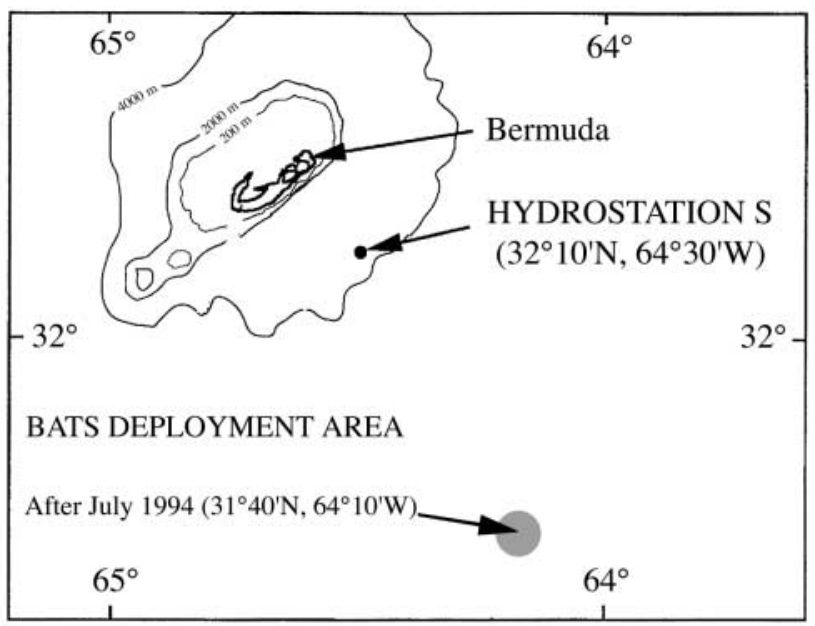

Fig. 1. Map of study site in the northwestern Sargasso Sea. Experimental water was collected from cruises to Hydrostation $\mathrm{S}$ and the BATS site. Bathymetry around Bermuda is shown 
Table 1. Water column conditions at the time of water collection for the Sargasso Sea seawater cultures and experimental parameters for nutrient enrichment experiments from 1997-1998. Mixed layer depth (MLD) during experimental period was determined as depth where sigma-t is equal to sea surface sigma-t plus an increment in sigma-t equivalent to a $0.2^{\circ} \mathrm{C}$ temperature decrease (Sprintall \& Tomczak 1992). All cultures were incubated in the dark at in situ temperatures

\begin{tabular}{|c|c|c|c|c|c|c|}
\hline Expt & Date & $\begin{array}{l}\text { Collection } \\
\text { depth } \\
\text { (m) }\end{array}$ & $\begin{array}{c}\text { MLD } \\
(\mathrm{m})\end{array}$ & $\begin{array}{l}\text { Incub. } \\
\text { temp. } \\
\left({ }^{\circ} \mathrm{C}\right)\end{array}$ & Treatments & $\begin{array}{c}\text { Time until } \\
\text { stationary growth } \\
\text { phase (d) }\end{array}$ \\
\hline \multirow[t]{6}{*}{ B106 } & Jul 97 & 5 & 12 & 27 & Control & 2.0 \\
\hline & & & & & $\mathrm{N}$ & 2.0 \\
\hline & & & & & $\mathrm{P}$ & 2.0 \\
\hline & & & & & $\mathrm{N}+\mathrm{P}$ & 2.0 \\
\hline & & & & & $\mathrm{C}$ & 2.0 \\
\hline & & & & & $\mathrm{C}+\mathrm{N}+\mathrm{P}$ & 2.5 \\
\hline \multirow[t]{5}{*}{ B107 } & Aug 97 & 5 & 13 & 28 & Control & 2.5 \\
\hline & & & & & $\mathrm{N}$ & 2.5 \\
\hline & & & & & $\mathrm{P}$ & 2.5 \\
\hline & & & & & $\mathrm{C}$ & 1.5 \\
\hline & & & & & $\mathrm{C}+\mathrm{N}+\mathrm{P}$ & 1.5 \\
\hline \multirow[t]{4}{*}{ HS 852} & Aug 97 & 5 & 13 & 28 & Control & 2.5 \\
\hline & & & & & $\mathrm{N}+\mathrm{P}$ & 2.5 \\
\hline & & & & & $\mathrm{C}$ & 2.9 \\
\hline & & & & & $\mathrm{C}+\mathrm{N}+\mathrm{P}$ & 2.5 \\
\hline \multirow[t]{6}{*}{ B115 } & Apr 98 & 10 & 102 & 20 & Control & 6.7 \\
\hline & & & & & $\mathrm{N}+\mathrm{P}$ & 6.7 \\
\hline & & & & & $\mathrm{C}$ & 3.6 \\
\hline & & & & & $\mathrm{C}+\mathrm{N}+\mathrm{P}$ & 2.5 \\
\hline & & & & & $\mathrm{C}+\mathrm{N}$ & 3.6 \\
\hline & & & & & $\mathrm{C}+\mathrm{P}$ & 3.6 \\
\hline \multirow[t]{4}{*}{ HS 875} & Aug 98 & 10 & 21 & 28.8 & Control & 3.7 \\
\hline & & & & & $\mathrm{N}+\mathrm{P}$ & 4.7 \\
\hline & & & & & C & 2.9 \\
\hline & & & & & $\mathrm{C}+\mathrm{N}+\mathrm{P}$ & 2.9 \\
\hline
\end{tabular}

centrations of $\mathrm{N}$ and $\mathrm{P}$ into the euphotic zone (Michaels \& Knap 1996, McGillicuddy \& Robinson 1997, Steinberg et al. 2001). DOC concentrations can increase by up to $6 \mu \mathrm{M} \mathrm{C}$ in the surface mixed layer during or shortly after convective mixing events (Hansell \& Carlson 2001). In addition, removal of DOC from surface to depth during convective mixing can introduce seasonally accumulated DOC into a depth horizon containing elevated macronutrients (i.e. >150 m; Carlson et al. 1994, Hansell \& Carlson 2001). Thus, we chose to add inorganic nutrients at concentrations of $\mathrm{N}$ and $\mathrm{P}$ similar to those observed at depths of the maximal BATS mixed layer depths (i.e. 250 to $300 \mathrm{~m}$ ) (Steinberg et al. 2001). However, the form of nitrogen added was $\mathrm{NH}_{4}$ instead of $\mathrm{NO}_{3}$. The chemical form and concentrations were the same as those used by Carlson \& Ducklow (1996), slightly lower than those used by Rivkin \& Anderson (1997), and similar to those used by Cotner et al. (1997), all of whom performed nutrient enrichment experiments in the northwestern Sargasso Sea.

Biological measurements. Bacterioplankton samples were fixed with particle-free $25 \%$ glutaraldehyde (final concentration $1.0 \%$ ) and stored at $4^{\circ} \mathrm{C}$ until slide preparation. All slides were prepared within $48 \mathrm{~h}$ of sample collection. Cells were filtered onto Irgalan black-stained $0.2 \mu \mathrm{m}$ polycarbonate filters, and samples were stained with either acridine orange (Hobbie et al. 1977) or 4'-6'-diamidino-2-phenylidole (DAPI; Porter \& Feig 1980), and enumerated with an Olympus AX-70 epifluorescence microscope $(1000 \times)$. In preliminary experiments comparing acridine orange with DAPI preparation, we did not observe any systematic variation in total prokaryotic counts at this oligotrophic site (unpubl. data). Flagellate abundances within the seawater cultures were reduced by $70 \%$ and remained at low concentrations for the first 3 to $7 \mathrm{~d}$ for most of the treatments. To obtain a general trend of microflagellate production within these seawater cultures we performed flagellate counts for all treatments in HS 875 and B115 and assumed these trends to be representative for all experiments. Flagellates were enumerated using the same slides used to count bacterioplankton. A minimum of 200 fields was counted per slide to obtain an estimate of flagellate abundance (Carlson \& Ducklow 1996).

DOC analysis. All DOC samples were analyzed on a custom-built high temperature combustion (HTC) analyzer designed by the Bermuda Biological Station's DOM research group. The configuration and operating parameters of this system are described thoroughly in Carlson et al. (1998). To avoid potential contamination from further filtration of culture medium, samples were drawn directly from the incubation carboy's spigot into pre-combusted glass vials. The DOC values include bacterial carbon; however, this accounts for less than $1 \%$ of bulk DOC concentrations (Carlson \& Ducklow 1996). Field samples collected from the surface mixed layer were not filtered so as to avoid potential contamination. Because particulate organic loads (organic matter retained on a GF/F filter) are less than 1 to $2 \%$ of total carbon the data are reported as DOC (Hansell \& Carlson 2001).

To avoid the small error associated with day-to-day instrument variability, all samples generated from 1 experiment were analyzed in a single day's run. Analysis of DOC utilization requires high precision and a stable baseline performance of the HTC system. A 
stable baseline was obtained by conditioning the machine extensively prior to analysis (Benner \& Strom 1993, Carlson \& Ducklow 1996). All samples were systematically checked against low carbon water and deep Sargasso Sea reference water (2600 m DOC ; $43 \pm$ $0.2 \mu \mathrm{MC})$. The reference waters were evaluated at every fourth to sixth analysis (Carlson \& Ducklow 1996, Hansell \& Carlson 1998).

Community structure analysis. Environmental DNA samples were collected during regular intervals from Expts B115 and HS 875. Cells were collected on a $0.22 \mu \mathrm{m}$ Supor filter (Gelman Scientific) from 250 to $500 \mathrm{ml}$ samples under gentle vacuum ( $100 \mathrm{~mm} \mathrm{Hg})$. Filters were placed into sealed plastic bags containing $2 \mathrm{ml}$ of sucrose lysis buffer $(20 \mathrm{mM}$ EDTA/400 mM NaCl/0.75 M sucrose/50 mM TrisHCL, pH 9.0) and stored at $-70^{\circ} \mathrm{C}$. Samples were then shipped, in liquid nitrogen, to S.J.G.'s laboratory at Oregon State University. Total cellular nucleic acids were isolated from the samples by lysis with Proteinase $\mathrm{K}\left(100 \mu \mathrm{g} \mathrm{ml} \mathrm{m}^{-1}\right)$ and sodium dodecyl sulfate (final 1\%), followed by a phenol/chloro form/isoamyl alcohol (25:24:1) extraction as previously described (Giovannoni et al. 1990). The purified environmental DNA was used as template for length heterogeneity polymerase chain reaction $(\mathrm{LH}-\mathrm{PCR}$; Suzuki et al. 1998).

LH-PCR is a high-resolution electrophoretic method for the analysis of rDNA diversity. Microbial community analysis by LH-PCR exploits the fact that length differences distinguish 16S rRNA genes in different phylogenetic clusters. Natural length polymorphisms in the 5' region of the molecules are reflected in the lengths of DNA fragments of the PCR amplicon. The method employs the resolving power and quantitative capabilities of the Perkin Elmer ABI-377 automated DNA sequencer (Applied Biosystems). Genescan software 3.01 (Applied Biosystems) was used to infer relative $16 \mathrm{~S}$ rDNA gene abundances in microbial communities from DNA fragment lengths, as described in detail by Suzuki et al. (1998). $10 \mathrm{ng}$ of purified genomic DNA from each sample was used as a template for LHPCR. The forward primer 27F (5'-AGA GTT TGA TCM TGG CTC AG-3') was 5' labeled with phosphoramidite dye 6-FAM (Applied Biosystems). The reverse primers used were 338R (5' GCW GCC WCC CGT AGG WGT$\left.3^{\prime}\right)$. The resulting electropherograms are highly reproducible (Suzuki \& Giovannoni 1996, Suzuki et al. 1998). Amplification preserves the proportions of genes in the starting mixtures with high fidelity, provided that product concentrations do not exceed critical levels. The PCR thermocycles were limited to just 20 in order to minimize reannealing bias and ensure the highest quality amplified product (Suzuki \& Giovannoni 1996).
Data analysis. Bacterioplankton production was measured as the increase in cell abundance from the initial time point of the experiment to the last point of exponential growth. The bacterioplankton production rates were determined from the slope of the linear regression of bacterioplankton abundance through these time points (Carlson \& Ducklow 1996). Differences among bacterial production slopes of various treatments within an experiment were determined by analysis of covariance (ANCOVA). Differences among DOC concentration, at various time points throughout an experiment or between experimental and field concentrations, were determined by analysis of variance (ANOVA). Stationary growth was defined as the portion of the growth curve (ln cell number versus time) when cell abundance ceased to increase. Statistical analysis including ANOVA and linear regression (Model 1) were performed using Statview (SAS Institute) or Super ANOVA (Abacus Concepts). All statistical analyses were considered significant at the 0.05 significance level.

\section{RESULTS}

\section{Field context}

The northwestern Sargasso Sea is characterized as a seasonally oligotrophic system influenced by seasonal patterns of temperature variability and mixing. DOC dynamics in the surface $40 \mathrm{~m}$ at BATS demonstrate a regular annual pattern of spring accumulation, summer constancy, and winter removal by water column overturn (Fig. 2). Following spring stratification of the water column, DOC builds up within the upper $40 \mathrm{~m}$. A net DOC increase of 3 to $5 \mu \mathrm{M} \mathrm{C}$ is reached by early June, and remains relatively stable at a mean concen-

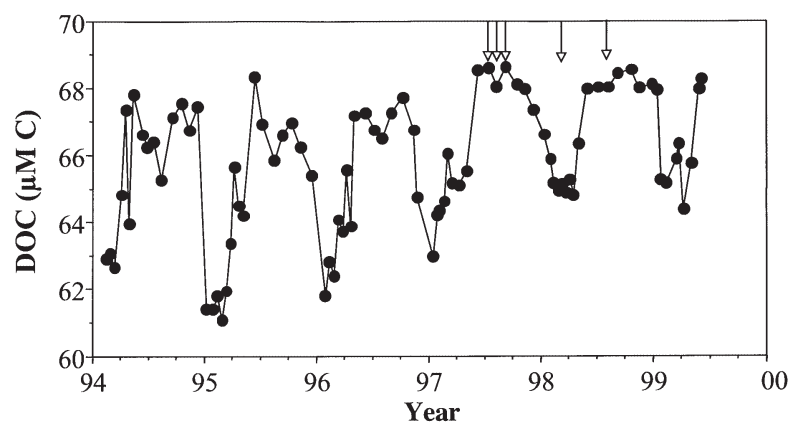

Fig. 2. Annual pattern of DOC concentrations measured in the surface $40 \mathrm{~m}$ at the BATS site (nominal sampling depths at 1 , $10,20,40 \mathrm{~m})$. Concentrations were calculated by integrating DOC stocks in the surface $40 \mathrm{~m}$ then dividing by the integration depth to obtain volumetric means. Arrows represent times when experiments were conducted 
tration of 67 to $68 \mu \mathrm{M} \mathrm{C}$ through the summer into autumn (Fig. 2). As temperatures cool in autumn and the mixed layer deepens, the surface DOC is diluted with low DOC water from depth. The resulting winter mixed layer concentration ranges from 61 to $66 \mu \mathrm{M} \mathrm{C}$, depending on the depth of the convective mixing. (See Carlson et al. 1994 and Hansell \& Carlson 2001 for more details of the annual DOC cycle at BATS.)

Seawater culture experiments were initiated with water collected from both the Hydrostation $\mathrm{S}$ and BATS sites (Fig. 1) in both thermally stratified (July 1997 and August 1997-98) and relatively mixed conditions (April 1998). Summer experiments were conducted when the surface mixed layer was $\leq 21 \mathrm{~m}$ and the mean DOC concentration was $68.3 \mu \mathrm{M}$, with in situ temperatures ranging from 27 to $28.8^{\circ} \mathrm{C}$ (Table 1 ). The April 1998 experiment was conducted during a mixing event when the mixed layer depths reached $102 \mathrm{~m}$. DOC concentrations within the mixed layer were $65.7 \mu \mathrm{M}$ and in situ temperature was $20^{\circ} \mathrm{C}$ (Table 1 ). Although the mixed layer was deeper in April 1998, the mixed layer depth was still shallow compared to the deepest mixing events $(>250 \mathrm{~m}$ ) observed at the BATS site. The April 1998 sampling period did not
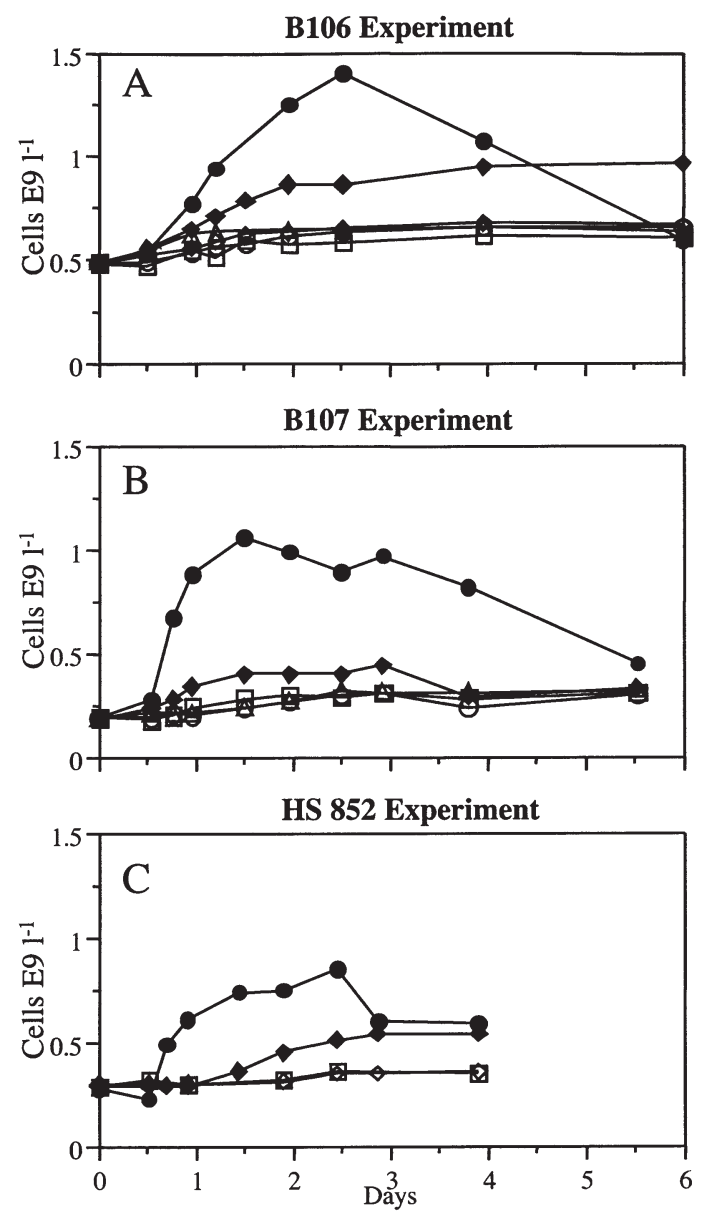

coincide with elevated biological activity or inorganic nutrient concentrations. Inorganic $\mathrm{N}$ and $\mathrm{P}$ were below the limits of detection by standard colorimetric techniques for all periods when experiments were set up (see www.bbsr.edu for BATS data set).

\section{Seawater cultures}

Bacterioplankton response to grazer reduction and nutrient amendment

Growth patterns for all but 2 treatments (HS 852 control and $\mathrm{N}+\mathrm{P}$ amendments) demonstrated familiar batch culture patterns of lag, exponential and stationary growth phases (Fig. 3) and significant production over the course of the incubation (Table 2). However, the magnitude of the bacterial production response varied significantly depending on the specific treatment (Fig. 3, Table 2). For example unamended controls showed only slight biomass production (albeit significant for all experiments except HS 852) over the course of the incubations. Bacterial production in treatments of just inorganic $\mathrm{N}$ or $\mathrm{P}$ additions, either individually or in
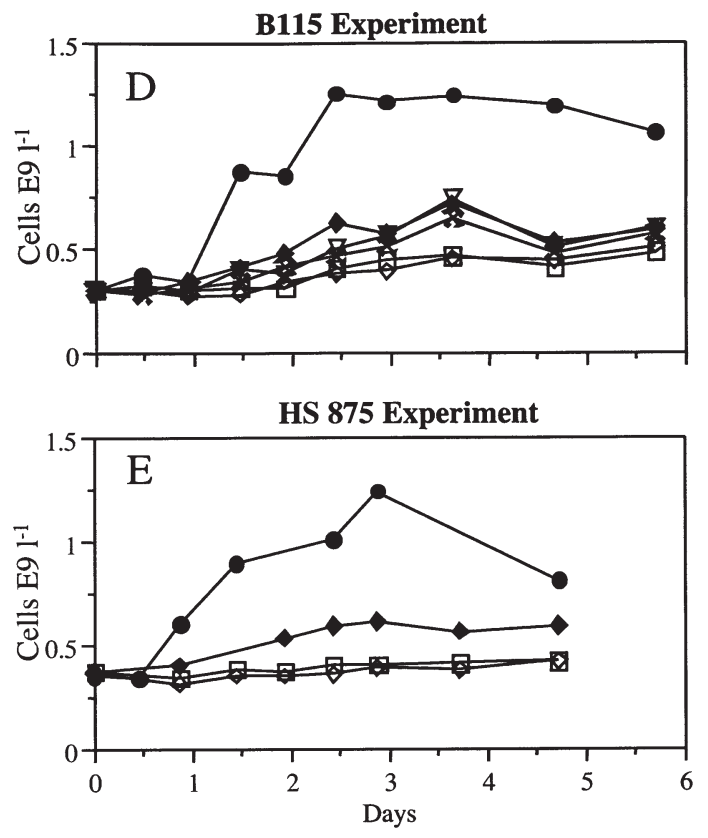

Fig. 3. Time-course of bacterial abundance for each nutrient enrichment culture. The treatments included a control $(\square), \mathrm{N}(\mathbf{O}), \mathrm{P}(\boldsymbol{\Delta}), \mathrm{N}+\mathrm{P}(\diamond), \mathrm{C}(\diamond), \mathrm{C}$ $+\mathrm{N}(\boldsymbol{\Delta}), \mathrm{C}+\mathrm{P}(\boldsymbol{\nabla}), \mathrm{C}+\mathrm{N}+\mathrm{P}(\bullet)$. Control, N, P and $\mathrm{N}+\mathrm{P}$ treatments were not significantly different for any experiment (see Table 2). Cultures that demonstrated minimal increase in bacterioplankton abundance did not utilize measurable concentrations of DOC (see Table 2). Data are presented for Expts (A) B106, (B) B107, (C) HS 852, (D) B115 and (E) HS 875 
combination, were also minimal and demonstrated no further enhancement of bacterioplankton production relative to the control treatments (significance level of 0.05 ; ANCOVA) (Table 2, Fig. 3). The addition of glucose produced a small but significant increase in bacterioplankton production in all seawater cultures (Table 2, Fig. 3). The addition of $\mathrm{C}+\mathrm{N}+\mathrm{P}$ yielded the most pronounced increase in bacterial abundance, with production rates 7 to 15 times greater than the control and inorganic treatments (Fig. 3, Table 2). Additional nutrient amendment treatments were introduced in Expt B115 to determine if labile DOC, in combination with a single inorganic amendment $\left(\mathrm{NH}_{4}\right.$ or $\left.\mathrm{PO}_{4}\right)$, would enhance bacterioplankton production compared to simple glucose amendment. While bacterioplankton production was significantly greater than in the control and inorganic treatments, neither the $\mathrm{C}+\mathrm{N}$ nor the $\mathrm{C}+\mathrm{P}$ enrichment enhanced bacterioplankton production beyond the glucose-only amendment (Fig. 3D, Table 2).

Diluting whole water by $70 \%$ with $0.2 \mu \mathrm{m}$ filtered seawater significantly reduced grazing pressure within each treatment. Similar to previous culture work reported for the Sargasso Sea (see Carlson \& Ducklow 1996), flagellate abundance remained low and at relatively unvarying concentrations in the seawater cultures for at least the first 2 to $3 \mathrm{~d}$ (Fig. 4).
Table 2. Bacterial production rates and DOC concentrations measured in nutrient enrichment experiments. Bacterial production rates were determined from the slope of the linear regression of bacterial abundance versus time through the end of logarithmic growth phase. $\triangle \mathrm{DOC}$ : change in DOC concentration between the initial time point of the experiment through the stationary phase of bacterial growth and extended incubation. -: no data collected. Values in parentheses are $\mathrm{SE}_{i} \mathrm{~ns}=$ not significant, $\mathrm{p}=0.05$

\begin{tabular}{|c|c|c|c|c|c|}
\hline \multirow[t]{2}{*}{ Expt } & \multirow[t]{2}{*}{ Treatment } & \multirow{2}{*}{$\begin{array}{l}\text { Bacterial } \\
\text { production } \\
\left(\text { cell } \mathrm{l}^{-1} \mathrm{~d}^{-1}\right)\end{array}$} & \multirow{2}{*}{$\begin{array}{c}\text { DOC } \\
(\mu \mathrm{M} C) \\
\text { Time zero }\end{array}$} & \multicolumn{2}{|c|}{$\begin{array}{l}\Delta \mathrm{DOC} \\
(\mu \mathrm{M} \mathrm{C})\end{array}$} \\
\hline & & & & $\begin{array}{c}\text { Stationary } \\
\text { phase }\end{array}$ & $\begin{array}{l}\text { Extended } \\
\text { incubation }\end{array}$ \\
\hline & & & & Day 6 & - \\
\hline \multirow{7}{*}{ B106 } & Control & $0.06(0.02)$ & $68.9(0.3)$ & ns & - \\
\hline & $\mathrm{N}$ & $0.07(0.01)$ & $69.5(0.7)$ & ns & - \\
\hline & $\mathrm{P}$ & $0.08(0.02)$ & $69.3(0.4)$ & ns & - \\
\hline & $\mathrm{N}+\mathrm{P}$ & $0.08(0.01)$ & $68.4(0.5)$ & ns & - \\
\hline & $\mathrm{C}$ & $0.20(0.01)$ & $79.5(0.4)$ & $9(0.7)$ & - \\
\hline & $\mathrm{C}+\mathrm{N}+\mathrm{P}$ & $0.40(0.03)$ & $79.7(0.3)$ & $13.7(0.6)$ & - \\
\hline & & & & Day 6 & - \\
\hline \multirow[t]{6}{*}{ B107 } & Control & $0.05(0.01)$ & $67.7(0.4)$ & $\mathrm{ns}$ & - \\
\hline & $\mathrm{N}$ & $0.05(0.01)$ & $67.2(0.6)$ & ns & - \\
\hline & $\mathrm{P}$ & $0.05(0.01)$ & $68.2(0.8)$ & ns & - \\
\hline & $\mathrm{C}$ & $0.15(0.02)$ & $78.7(0.7)$ & $7.6(0.9)$ & - \\
\hline & $\mathrm{C}+\mathrm{N}+\mathrm{P}$ & $0.64(0.13)$ & $79.0(0.3)$ & $11.8(0.6)$ & - \\
\hline & & & & Day 11 & Day 32 \\
\hline \multirow[t]{5}{*}{ HS 852} & Control & $0.02(0.01)^{\mathrm{a}}$ & $68.5(0.7)$ & $\frac{x_{1}+1}{\mathrm{~ns}}$ & $\frac{\mathrm{ng}}{\mathrm{ns}}$ \\
\hline & $\mathrm{N}+\mathrm{P}^{\mathrm{a}}$ & $0.02(0.01)^{\mathrm{a}}$ & $68.9(0.8)$ & ns & $\mathrm{ns}$ \\
\hline & $\mathrm{C}$ & $0.10(0.01)$ & $80.9(0.4)$ & $4.1(0.4)$ & $9.3(0.4)$ \\
\hline & $\mathrm{C}+\mathrm{N}+\mathrm{P}$ & $0.26(0.05)$ & $80.9(0.4)$ & $10.4(0.6)$ & $17.2(0.6)$ \\
\hline & & & & Day 7 & Day 33 \\
\hline \multirow[t]{7}{*}{ B115 } & Control & $0.04(0.01)$ & $66.3(0.6)$ & $\mathrm{ns}$ & $\mathrm{ns}$ \\
\hline & $\mathrm{N}+\mathrm{P}$ & $0.04(0.004)$ & $66.1(0.6)$ & ns & ns \\
\hline & $\mathrm{C}$ & $0.12(0.01)$ & $78.6(0.9)$ & $7.4(1.1)$ & $7.2(0.9)$ \\
\hline & $\mathrm{C}+\mathrm{N}+\mathrm{P}$ & $0.39(0.07)$ & $77.9(0.9)$ & $14.2(1.1)$ & $16(1.0)$ \\
\hline & $\mathrm{C}+\mathrm{N}$ & $0.10(0.01)$ & $75.4(0.3)$ & $8.0(0.7)$ & $9.7(0.7)$ \\
\hline & $\mathrm{C}+\mathrm{P}$ & $0.12(0.02)$ & $75.4(0.3)$ & $7.1(0.7)$ & $8.8(0.4)$ \\
\hline & & & & Day 8 & Day 69 \\
\hline \multirow[t]{4}{*}{ HS 875} & Control & $0.02(0.004)$ & $68.6(0.6)$ & ns & ns \\
\hline & $\mathrm{N}+\mathrm{P}$ & $0.02(0.01)$ & $68.8(0.3)$ & ns & ns \\
\hline & $\mathrm{C}$ & $0.09(0.01)$ & $79.1(0.4)$ & $8.9(0.5)$ & $10.5(0.7)$ \\
\hline & $\mathrm{C}+\mathrm{N}+\mathrm{P}$ & $0.31(0.04)$ & $79.2(0.5)$ & $10.3(0.6)$ & $13.3(0.7)$ \\
\hline
\end{tabular}

${ }^{\text {a }}$ Slope of the linear regression is not significant from zero at the 0.05 significance level

\section{Change in DOC concentrations in seawater cultures}

One principal objective was to assess whether reducing bacterioplankton grazing pressure or adding organic and inorganic nutrients would stimulate remineralization of naturally occurring DOC, thus drawing concentrations down to levels lower than those observed within the BATS mixed layer. As a point of reference, DOC concentrations were sampled from the mixed layer and compared to DOC concentrations collected at the initiation of each experiment, and from at least 1 time point in the stationary phase (Fig. 5, Table 2). In cultures where the initial DOC concentration was not greater than the in situ mixed layer concentrations the resulting bacterioplankton production was minimal and DOC removal could not be resolved (at $\mu \mathrm{M}$ scale). These data indicate that surface water bacterial assemblages were incapable of utilizing the seasonally accumulated DOC as a substrate to support rapid bacterial production. In addition, none of the control, N, P, or N+P treatments demonstrated any significant removal of DOC over the time scale of these experiments; values remained the same as the mixed layer DOC concentrations. Increasing incubation time had no measurable effect on DOC utilization for these treatments (Fig. 5, Table 2). In the $\mathrm{C}, \mathrm{C}+\mathrm{N}$ and $\mathrm{C}+\mathrm{P}$ treatments, anywhere from 32 to $80 \%(4$ to $9 \mu \mathrm{M} \mathrm{C}$ ) of the added labile DOC was utilized by the stationary phase (Fig. 5, Table 2) and as much as $100 \%$ of the added DOC was utilized in extended incubations of 1 

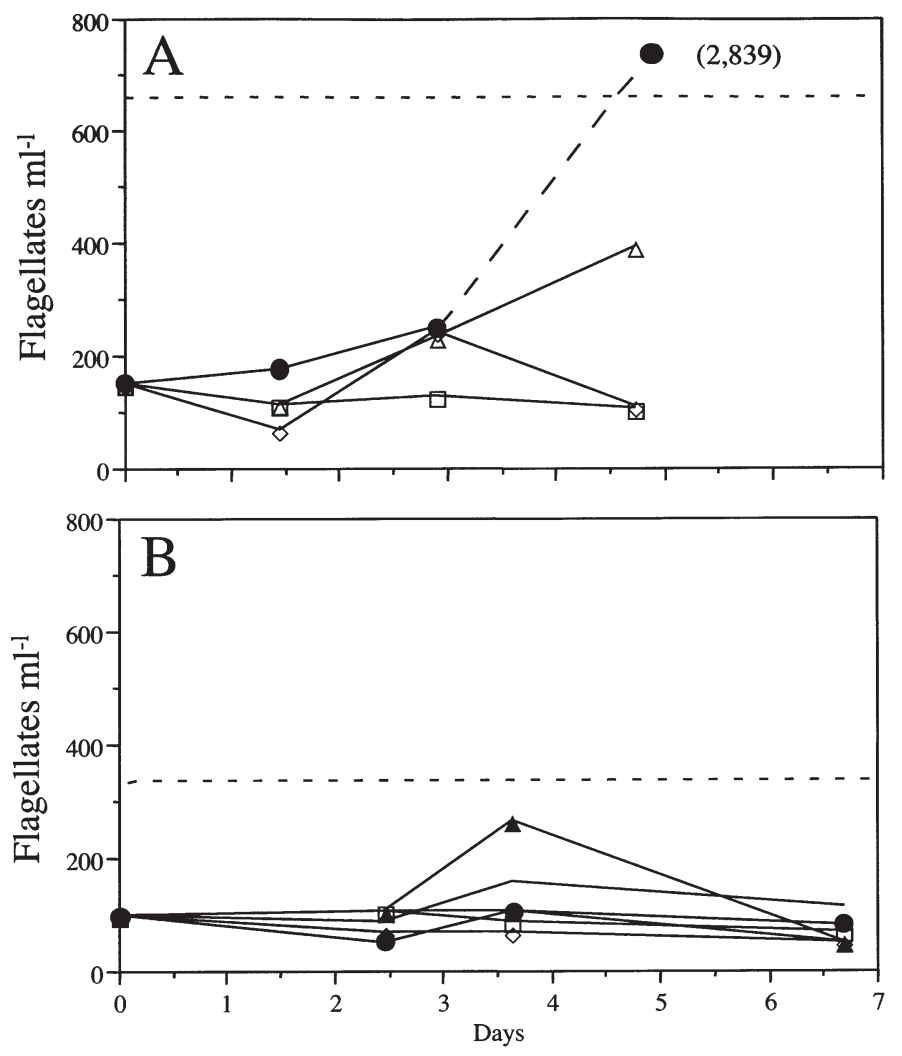

Fig. 4. Time-course of flagellate concentration for nutrient enrichment culture (A) HS 875 and (B) B115 for the control $(\square), \mathrm{N}+\mathrm{P}(\diamond), \mathrm{C}(\diamond), \mathrm{C}+\mathrm{N}(\boldsymbol{\Delta}), \mathrm{C}+\mathrm{P}(\boldsymbol{\nabla})$ and $\mathrm{C}+\mathrm{N}+\mathrm{P}(\boldsymbol{\bullet})$ treatments. Horizontal dashed line represents the estimate of flagellate concentration measured in whole water. Sloping dashed line connects to data that are off the scale in (A). This data point represents flagellate concentration in $\mathrm{C}+\mathrm{N}+\mathrm{P}$ for Expt HS 875

to 2 mo (Fig. 5D, E). While $\mathrm{C}, \mathrm{C}+\mathrm{N}$ and $\mathrm{C}+\mathrm{P}$ treatments resulted in the removal of most, if not all, of the amended DOC, there was no further removal of DOC to levels below the mixed layer concentration. These data indicate that the seasonally accumulated mixed layer DOM was not used to support the observed bacterial growth, but that the observed growth was supported by the labile DOC amendment (glucose).

$\mathrm{C}+\mathrm{N}+\mathrm{P}$ treatments demonstrated the most rapid removal of amended DOC compared to all other treatments. In 4 of the 5 experiments, the entire DOC amendment was utilized by the stationary phase (Fig. 5, Table 2). In Expts B106 and B115, an additional $2 \mu \mathrm{M} C$ was removed by the stationary growth phase, indicating a net removal of 'semi-labile' DOC. Extended incubations of the $\mathrm{C}+\mathrm{N}+\mathrm{P}$ treatments for Expts HS 852, B115, and HS 875 reduced DOC below mixed layer concentrations by $4.4 \mu \mathrm{M} \mathrm{C}, 3.3 \mu \mathrm{M} \mathrm{C}$ and $2.9 \mu \mathrm{M} \mathrm{C}$, respectively (Fig. 5, Table 2), again indicating microbial remineralization of 'semi-labile' DOC.
Community structure

LH-PCR is a method for displaying bacterioplankton diversity. The peaks in an LH-PCR electropherogram correspond to rDNA genes that have been amplified and electrophoretically separated, with molecule length indicated on the horizontal axis and relative gene abundance on the vertical axis (measured as relative fluorescence). LH-PCR is highly reproducible, but peak sizes do not quantitatively reflect microbial abundances because of variations in the copy number of rDNA genes in cells, biases in the PCR, and some overlap in the lengths of genes originating from different species. Nonetheless, this simple technique effectively reveals broad changes in microbial communities and also provides useful preliminary information about the phylogenetic composition of the community. Unfortunately, whole water samples were not collected at the time these experiments were conducted. However, the bacterioplankton assemblage present in the time zero $(T-0)$ time point of the control treatment of the spring B115 experiment is similar to a typical electropherogram of whole water collected during the spring in the surface $10 \mathrm{~m}$ at BATS (Fig. 6). We present this comparison to demonstrate that experimental preparation did not dramatically alter the composition of the naturally occurring assemblage, at least within the resolution of our analyses. Furthermore, we present electropherograms for each treatment at 3 time points throughout the incubation for experiment B115 (Fig. 7). Table 3 presents the percentage of total integrated peak area represented by each DNA fragment length. These values reflect relative changes in community composition between treatments.

Electropherograms from Expt B115 (Fig. 7, Table 3) are representative of the community structure shifts observed for all the nutrient enrichment experiments sampled. The electropherograms for the control and inorganic amendment treatments gave similar temporal patterns; heterogeneity of the initial bacterioplankton assemblage remained relatively stable with slight variability in the percent contribution of individual peaks to the total integrated peak area (Fig. 7, Table 3). The diversity of major peaks observed in the control treatments appeared to be conserved in the $\mathrm{C}$ (except Day 2), $\mathrm{C}+\mathrm{N}$ and $\mathrm{C}+\mathrm{P}$ treatments. However, the relative contribution of those individual peaks varied considerably. Clear temporal shifts in community structure were observed for the $\mathrm{C}+\mathrm{N}+\mathrm{P}$ treatment compared to the other treatments. After $2 \mathrm{~d}$ of incubation, the heterogeneity of the community structure was reduced to 2 major peaks with species associated with DNA fragment lengths of $341 \mathrm{bp}$ (base pair) and $361 \mathrm{bp}$ dominating. This trend persisted throughout the first 

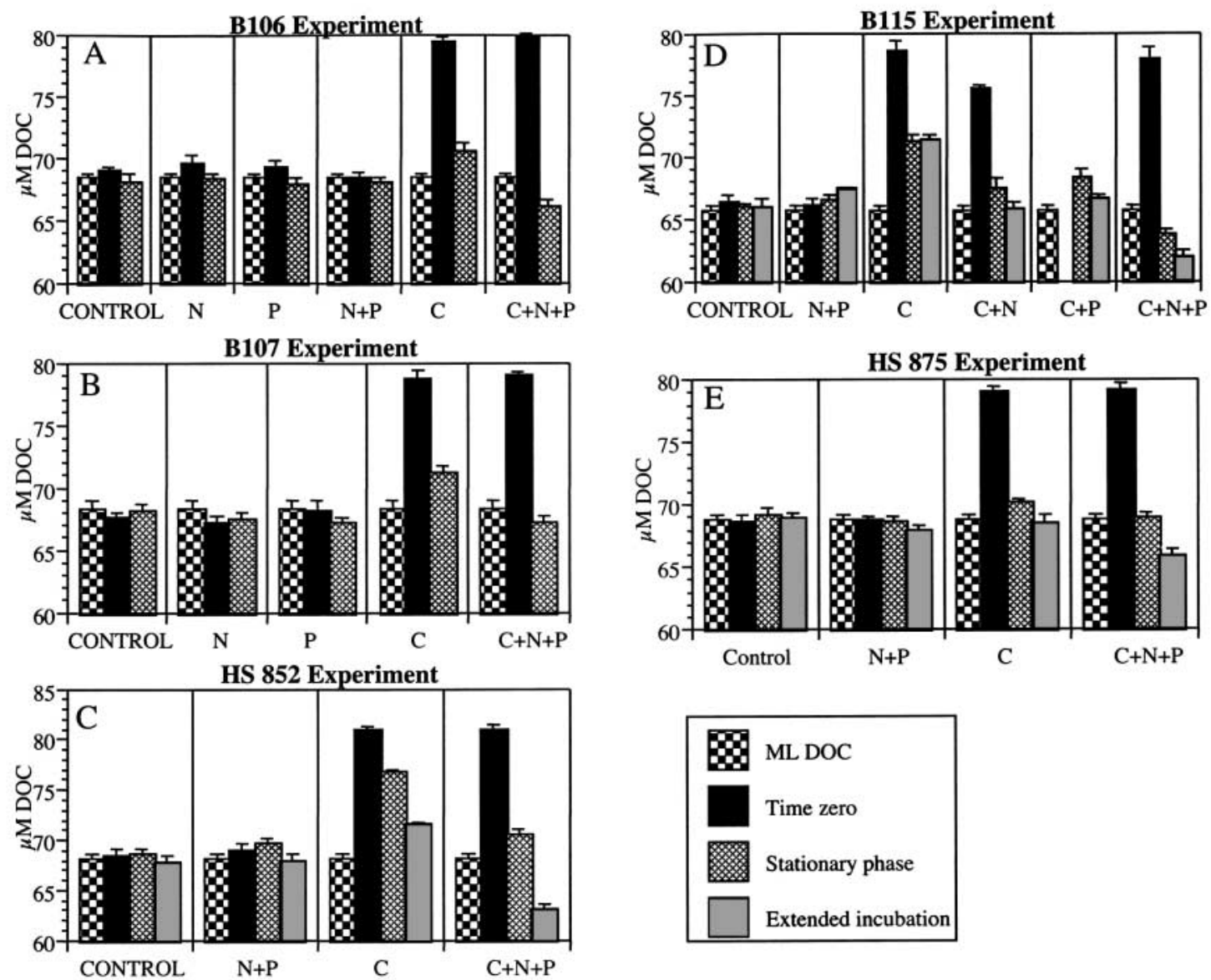

Fig. 5. DOC concentrations measured in the mixed layer (ML) and at various time points throughout the experiments including a sample from time zero, stationary growth phase, and after extended incubation (see Table 2 for times). Data are presented for Expts (A) B106, (B) B107, (C) HS 852, (D) B115 and (E) HS 875. Extended incubations were conducted for Expts HS 852, B115 and HS 875. Time zero sample for B115 C+P treatment was lost. Error bars represent standard error

Fig. 6. Electropherograms of DNA fragments amplified by PCR for samples collected from (A) whole water collected from $10 \mathrm{~m}$ in March of 2001, (B) time zero of the control treatment of Expt B115 (seawater culture)
Amplicon Length (bp)

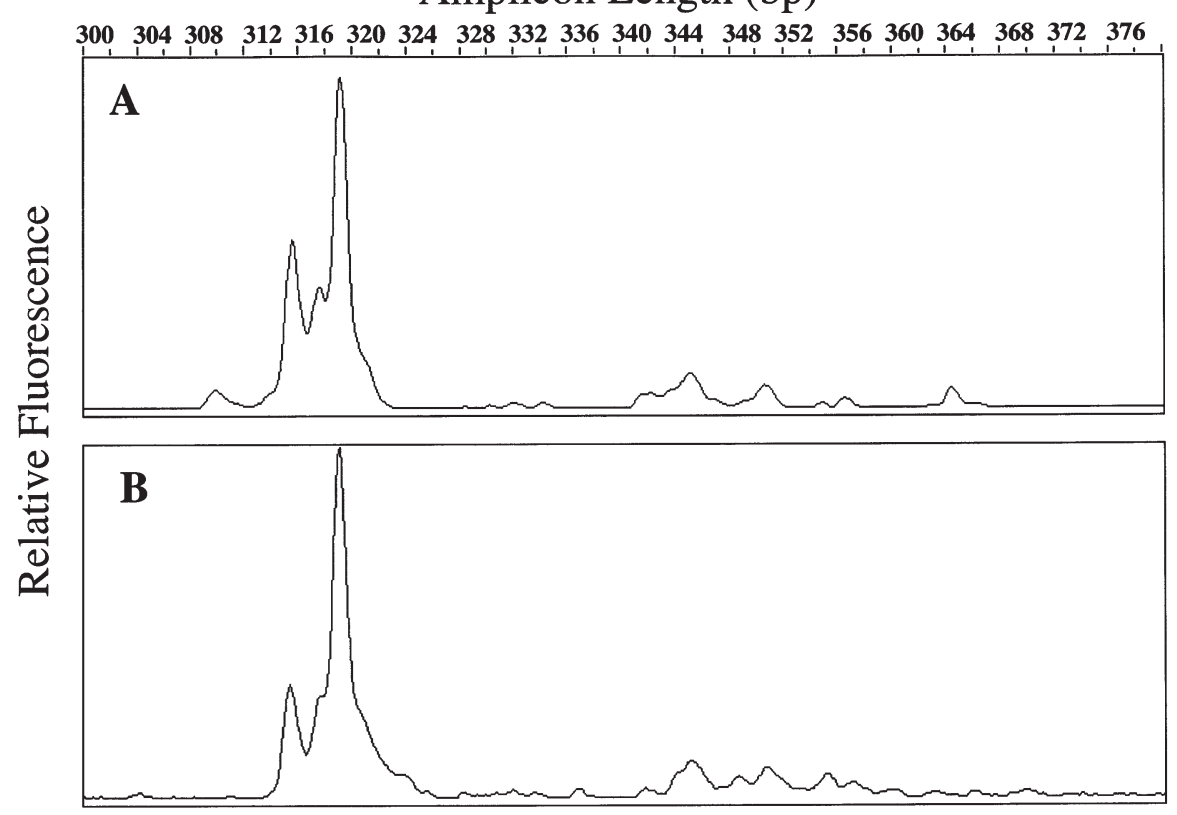




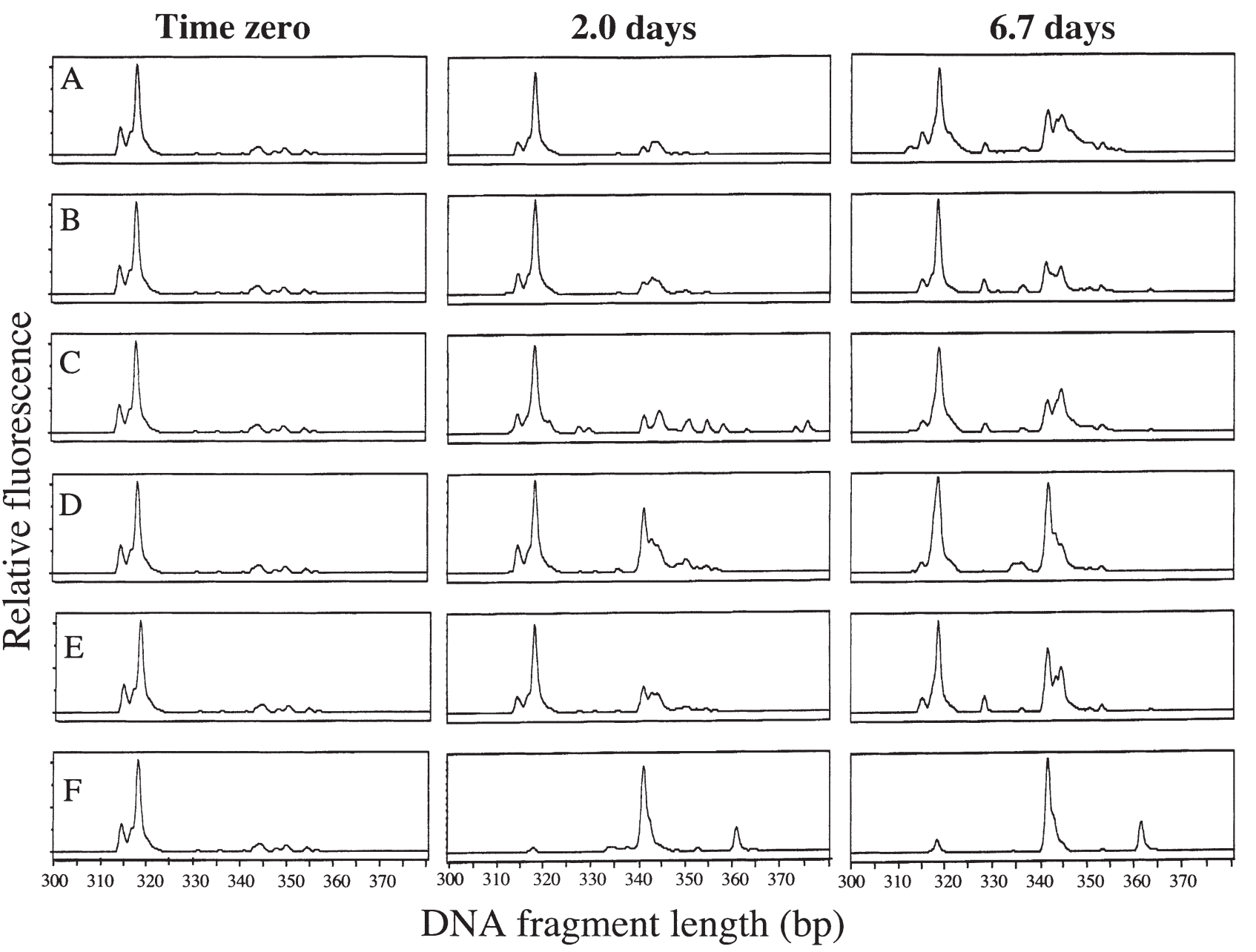

Fig. 7. Electropherograms of DNA fragments amplified by PCR for Expt B115. Rows represent treatment and columns represent incubation time. Each row displays the temporal shift in diversity of bacterioplankton community structure for (A) control, (B) $\mathrm{N}+\mathrm{P},(\mathrm{C}) \mathrm{C},(\mathrm{D}) \mathrm{C}+\mathrm{N},(\mathrm{E}) \mathrm{C}+\mathrm{P}$ and $(\mathrm{F}) \mathrm{C}+\mathrm{N}+\mathrm{P}$. Columns represent days of incubation. Time zero for each treatment is represented by the electropherogram generated for the control treatment

week of the incubation (Fig. 7, Table 3). The dramatic shift associated with $\mathrm{C}+\mathrm{N}+\mathrm{P}$ additions was also coincident with the largest increase in bacterial abundance and greatest reduction of 'semi-labile' DOC.

\section{DISCUSSION}

Accumulation of DOC is due to the temporal uncoupling of production and consumption processes. What factors affect the consumption mechanisms, thereby allowing for accumulation? The 'malfunctioning microbial loop' hypothesis (Thingstad et al. 1997) states that the various factors which control bacterioplankton production can reduce the capacity of bacterioplankton to remineralize otherwise utilizable $\mathrm{DOC}$, resulting in its accumulation. These factors can include temperature (Pomeroy \& Deibel 1986, Pomeroy et al. 1991, Shiah \&
Ducklow 1994), grazing pressure (Thingstad et al. 1997) or mineral nutrient availability (Zweifel et al. 1993, Søndergaard \& Middelboe 1995, Thingstad \& Rassoulzadegan 1995, Cotner et al. 1997, Rivkin \& Anderson 1997, Thingstad et al. 1998, Caron et al. 2000). Other studies argue that DOC accumulation and reduced microbial remineralization result from the biological production of recalcitrant compounds that are resistant to rapid microbial degradation (Billen \& Fontigny 1987, Brophy \& Carlson 1989, Toggweiler 1989, Legendre \& Le Fevre 1995, Carlson et al. 1998). Recent studies have identified unmodified recalcitrant components of DOM that were formed by direct biosynthesis (Tanoue et al. 1995, Aluwihare et al. 1997, McCarthy et al. 1998). In addition to biosynthesis of recalcitrant compounds, abiotic processes such as condensation reactions (Harvey et al. 1983), adsorption to colloids (Nagata \& Kirchman 1996) or exposure to UV 
Table 3. Percentage of total integrated electropherogram peak area represented by each DNA fragment length in Expt B115. Genomic DNA was isolated from each experimental treatment over 4 time points (see text). Only values greater than $0.5 \%$ were included in the table. All values of equal to or greater than $10 \%$ of integrated peak area are in bold print

\begin{tabular}{|c|c|c|c|c|c|c|c|c|c|c|c|c|c|c|c|c|c|c|c|c|c|c|c|c|}
\hline \multirow{2}{*}{$\begin{array}{l}\text { Time } \\
\text { point (d) }\end{array}$} & \multicolumn{24}{|c|}{-DNA fragment length (bp) } \\
\hline & 312 & 314 & 315 & 317 & 318 & 321 & 327 & 328 & 329 & 334 & 336 & 338 & 341 & 343 & 344 & 348 & 349 & 350 & 352 & 353 & 354 & 358361 & 366 & 378 \\
\hline \multicolumn{25}{|l|}{ Control } \\
\hline 0 & & & 14 & 10 & 56 & & & & & & 1 & & 1 & & 8 & 2 & & 4 & & & 2 & & & \\
\hline 2 & & & 8 & & 64 & & & 1 & & & 1 & & 4 & 7 & 10 & 1 & & 2 & & & 1 & & & \\
\hline 3.6 & 3 & & 7 & & 41 & & 2 & & & & 2 & & 10 & 6 & 19 & & & 3 & & 2 & 1 & & & \\
\hline 6.7 & & & 7 & & 51 & & 3 & & & & 1 & & 9 & 8 & 14 & 1 & & 3 & & 2 & 1 & & & \\
\hline \multicolumn{25}{|l|}{$\mathbf{N}+\mathbf{P}$} \\
\hline 0 & & & 14 & 10 & 56 & & & & & & 1 & & 1 & & 8 & 2 & & 4 & & & 2 & & & \\
\hline 2 & 1 & & 11 & & 59 & & & & & & 1 & & 6 & 17 & & 1 & & 2 & & & 1 & & & \\
\hline 3.6 & & 7 & & & 41 & & 1 & & & & 1 & & 13 & 11 & 15 & 3 & & 3 & 1 & & 1 & & & \\
\hline 6.7 & & & 6 & & 45 & & 4 & & & & 3 & & 19 & & 13 & 1 & & 2 & 3 & & 1 & & & \\
\hline \multicolumn{25}{|l|}{$\mathbf{C}$} \\
\hline 0 & & & 14 & 10 & 56 & & & & & & 1 & & 1 & & 8 & 2 & & 4 & & & 2 & & & \\
\hline 2 & & & 7 & & 44 & 5 & 2 & & 2 & & & & 6 & & 12 & 2 & & 6 & & & 4 & 3 & & 4 \\
\hline 3.6 & 2 & 6 & & & 35 & & & 2 & & & 2 & & 12 & 6 & 22 & & 3 & & 3 & & 1 & & & \\
\hline 6.7 & 1 & & 4 & & 43 & & & 3 & & & 2 & & 11 & & 28 & & & 3 & & 3 & & & & \\
\hline \multicolumn{25}{|l|}{$\mathrm{C}+\mathrm{N}$} \\
\hline 0 & & & 14 & 10 & 56 & & & & & & 1 & & 1 & & 8 & 2 & & 4 & & & 2 & & & \\
\hline 2 & & & 8 & & 37 & & & & & & 1 & & 18 & 10 & 11 & & 3 & 5 & & 1 & 2 & & & \\
\hline 3.6 & & & 4 & & 24 & & & 1 & & 11 & & & 28 & 11 & 14 & 2 & & 2 & & 2 & 1 & & & \\
\hline 6.7 & & & 3 & & 41 & & & & & 3 & 4 & & 25 & 9 & 10 & 1 & & 1 & & 1 & & & & \\
\hline \multicolumn{25}{|l|}{$\mathbf{C}+\mathbf{P}$} \\
\hline 0 & & & 14 & 10 & 56 & & & & & & 1 & & 1 & & 8 & 2 & & 4 & & & 2 & & & \\
\hline 2 & & & 8 & & 49 & & 1 & & & & 1 & & 11 & 8 & 11 & 2 & & 4 & 1 & & 2 & & & \\
\hline 3.6 & & & 6 & & 37 & & 2 & & & & 2 & & 15 & 11 & 16 & 2 & & 3 & 1 & & 1 & & & \\
\hline 6.7 & & & 5 & & 37 & & 4 & & & & 1 & & 21 & 9 & 19 & & & 1 & 2 & & & & & \\
\hline \multicolumn{25}{|l|}{$\mathrm{C}+\mathrm{N}+\mathrm{P}$} \\
\hline 0 & & & 14 & 10 & 56 & & & & & & 1 & & 1 & & 8 & 2 & & 4 & & & 2 & & & \\
\hline 2 & & & & & 3 & & & & & 1 & & & 48 & 22 & & & & & & 2 & & 22 & & \\
\hline 3.6 & & & & & 4 & & & & & 7 & & 5 & 65 & & & 2 & & & & 3 & & 13 & 2 & \\
\hline 6.7 & & & & & 9 & & & & & 1 & & & 69 & & & & & & & 1 & & 18 & & \\
\hline
\end{tabular}

irradiation (Keil \& Kirchman 1994, Benner \& Biddanda 1998) can result in the transformation of labile compounds to refractory compounds that accumulate. DOC that resists rapid microbial attack and turns over on time-scales of months to years is often referred to as 'semi-labile' DOC (Kirchman et al. 1993, Carlson \& Ducklow 1995, Cherrier et al. 1996, Søndergaard et al. 2000). Bioassays can be used to determine the availability of naturally occurring DOM substrates to bacterioplankton and can provide insight into factors that affect DOC consumption, resulting in its accumulation.

Seawater cultures are often used to assess bacterioplankton growth dynamics (Kirchman et al. 1982, Ammerman et al. 1984, Chin-Leo \& Kirchman 1990, Toolan et al. 1991, Ducklow et al. 1992, Rivkin \& Anderson 1997, Ducklow et al. 2000) and availability of naturally occurring substrates to bacterioplankton (Barber 1968, Ogura 1972, Kirchman et al. 1991, Kroer 1993, Zweifel et al. 1993, Amon \& Benner 1994, Carlson \& Ducklow 1996, Cherrier et al. 1996, Carlson et al. 1999). However, there are fundamental biases associ- ated with this experimental design in that it uncouples DOC production and consumption processes and forces heterotrophic bacterioplankton assemblages to utilize organic matter that has accumulated. These accumulated substrates may not be representative of those that support most in situ bacterial production in the euphotic zone on short time-scales and therefore may bias bacterioplankton growth estimates determined from seawater cultures. However, this experimental design is well suited for determining the availability of accumulated organic material to bacterioplankton assemblages and assessing factors influencing its utilization.

Direct measurements of bacterial abundance, DOC concentrations, and bacterioplankton community structure were obtained from 5 seawater culture experiments to assess the role of the 'malfunctioning microbial loop' (Thingstad \& Rassoulzadegan 1995, Thingstad et al. 1997) in the surface waters of the northwestern Sargasso Sea. Points of interest from analyses of these data include: (1) surface bacterio- 
plankton assemblages were unable to remineralize the seasonally accumulated DOC ( $\mu \mathrm{M}$ resolution) on the time-scales of these experiments; (2) utilization of seasonally accumulated DOC was not enhanced by adding inorganic nutrient $\mathrm{N}$ or $\mathrm{P}_{i}$ (3) labile DOC amendments stimulated bacterial production, indicating that the bacterioplankton assemblage was initially energy limited (labile DOC amendments were utilized rapidly even in the absence of measurable inorganic nutrients); (4) the combination of labile organic matter with inorganic nutrients $(\mathrm{C}+\mathrm{N}+\mathrm{P}$ amendments) produced a set of conditions that promoted utilization of seasonally accumulated ('semi-labile' DOC); and (5) changes in bacterioplankton community rDNA gene profiles were only minor in the control and inorganic treatments; however, utilization of seasonally accumulated DOC in CNP treatments coincided with significant changes in bacterioplankton community structure. These data suggest the possibility that bacterioplankton community structure, as well as nutrient regime, may be important factors governing the utilization of recalcitrant DOC substrates.

\section{Availability of seasonally accumulated DOM to surface bacterioplankton assemblages}

Seawater culture bioassays are a useful way to assess the percentage of naturally occurring DOC that is available to bacterioplankton on time-scales of hours to days. In a previous study, Carlson \& Ducklow (1996) estimated that 0 to $6 \%$ of the accumulated DOC pool in the waters around Bermuda was available to surface water bacterioplankton. However, it must be noted that in their study bacterioplankton production and DOC consumption was only observed in experiments where the initial DOC concentration was greater than the mixed layer concentration at BATS (see their Fig. 2). The observations of the present study are consistent with the previous findings of Carlson \& Ducklow (1996), who found that when DOC concentrations were equal to mean mixed layer concentrations at BATS the DOM composition supported neither rapid bacterial production nor measurable DOC remineralization. Cherrier et al. (1996) reported similar findings for the eastern North Pacific where neither bacterioplankton production nor DOC removal were measurable in 3 out of 4 unamended seawater culture experiments.

We hypothesize that the microbial assemblage that develops within the euphotic zone is adapted to low inorganic nutrient concentrations, and obtains its $\mathrm{C}$ and energy demands from instantaneously produced DOM that is leaked from the grazing food web and constrained by the magnitude of primary production. During periods of stratification, DOM production and consumption are tightly coupled, preventing further accumulation of DOM in the summer through autumn periods. Based on the results presented here, the bacterial assemblage that develops in the low nutrient/high light environment appears to be poorly adapted for utilizing more recalcitrant compounds.

\section{Inorganic nutrients and seasonal accumulation of DOC at BATS}

Seasonal DOC accumulation and vertical export was observed in the northwestern Sargasso Sea near Bermuda (Carlson et al. 1994, Hansell \& Carlson 2001). If the low supply of macronutrients was limiting bacterioplankton production and thus responsible for the seasonal accumulation of degradable DOC, then we might have expected to see increased bacterial growth and DOC removal in cultures enriched with $\mathrm{NH}_{4}$ and $\mathrm{PO}_{4}$. In contrast to this expectation, bacterial production was minimal and DOC utilization was immeasurable (on the $\mu \mathrm{M}$ scale) for the control, $\mathrm{N}, \mathrm{P}$, or $\mathrm{N}+\mathrm{P}$ treatments. Cherrier et al. (1996) also demonstrated that inorganic amendments had no effect on either bacterial production or DOC uptake in the eastern North Pacific. Søndergaard et al. (2000) found that inorganic nutrient amendments had only a marginal effect on DOC degradation. These studies suggest that it is the recalcitrant nature of the seasonally accumulated DOC that constrains bacterial production and DOC utilization, and not solely inorganic nutrient availability.

However, additions of inorganic $\mathrm{N}$ and $\mathrm{P}$ have also been shown to stimulate bacterial production for other experiments conducted in the vicinity of BATS (Cotner et al. 1997, Rivkin \& Anderson 1997, Caron et al. 2000). DOC was not measured during these studies, making it difficult to assess how the observed bacterial response affected DOC concentrations relative to mean mixed layer concentrations, or if initial in situ conditions may have affected bacterial responses and subsequent substrate utilization. For example, transient events, such as phytoplankton blooms or mesoscale eddies (McGillicuddy \& Robinson 1997, McGuillicuddy et al. 1998), can affect DOC sourcesink relationships resulting in short-term accumulation of bioavailable DOC (Carlson et al. 2000, Søndergaard et al. 2000). Cotner et al.'s (1997) March 1993 experiment coincided with the annual spring phytoplankton bloom (see www.bbsr.edu for details; Michaels \& Knap 1996) and rapid DOC production in the surface $250 \mathrm{~m}$ (Carlson et al. 1994). The largest increase in bacterial production in their experiment was with $\mathrm{PO}_{4}$ enrichment; thus, it is possible that increased phytoplankton and associated biological activity alleviated C limita- 
tion, allowing bacterioplankton to respond to $\mathrm{PO}_{4}$ additions. It is also possible that the quality of DOM produced during convective overturn (spring bloom) differed from DOC quality produced during stratified conditions. Nonetheless, stimulation of bacterioplankton production upon the addition of inorganic $\mathrm{N}$ or $\mathrm{P}$ indicates the presence of a labile DOC pool during previous studies (Cotner et al. 1997, Rivkin \& Anderson 1997, Caron et al. 2000) that was not observed in this study.

The present experiments were performed under grazer-reduced conditions. Grazers can recycle nutrients required by bacterioplankton (Strom 2000). We assumed that the chemical form of these recycled nutrients is similar to that used in the experimental amendments; however, we cannot rule out the possibility that other compounds other than $\mathrm{NH}_{4}$ and $\mathrm{PO}_{4}$ in material released by bacteriovores permit the utilization of recalcitrant DOM.

\section{Energy limitation and the utilization of degradable DOC}

Bacterioplankton production was stimulated by the addition of glucose (Fig. 3, Table 2), indicating that the surface water bacterioplankton assemblage was initially energy limited (Kirchman 1990, Kirchman et al. 1990, Carlson \& Ducklow 1996, Cherrier et al. 1996, Church et al. 2000). Others have found that the addition of labile carbon together with inorganic nutrients can stimulate bacterial production more than the sole addition of labile carbon (Pomeroy et al. 1995, Cotner et al. 1997, Rivkin \& Anderson 1997, Shiah et al. 1998, Thingstad et al. 1998, Church et al. 2000, Donachie et al. 2001), indicating that energy and nutrient limitation can coexist. In the present study the small increase in bacterial biomass indicates that once energy limitation was alleviated a secondary limitation was evoked. However, despite the small response in bacterial abundance in the $\mathrm{C}$ treatments, glucose carbon was reduced by 33 to $85 \%$ (4 to $9 \mu \mathrm{M} \mathrm{C}$ ) within the first few days, and up to $100 \%$ over the time-scale of weeks (Fig. 5, Table 2). Although the labile DOC was utilized inefficiently, the glucose $\mathrm{C}$ was subject to rapid remineralization even without the addition of inorganic nutrients. Baxter \& Sieburth (1984) speculated that high glucose uptake with low growth efficiency is due to the production of cellular storage products. Burney (1986) also demonstrated rapid utilization of surplus carbohydrates in unamended dark incubations performed in the Sargasso Sea. These studies indicate that degradable DOC is used by microorganisms despite a lack of measurable macronutrients in the surface waters. In their review, del Giorgio \& Cole (2000) dis- cussed the possibility that bacteria will maximize their rate of catabolism of available $\mathrm{C}$ even when inorganic nutrients are not available. The potential advantages of this strategy might be to maintain high electrochemical potentials across cell membranes to support active transport functions and motility, both of which would leave cells poised to exploit transient increases in macronutrients associated with patchy nutrient distributions (del Giorgio \& Cole 2000).

In the $\mathrm{C}, \mathrm{C}+\mathrm{N}$ and $\mathrm{C}+\mathrm{P}$ treatments, the utilization of DOC was restricted to the amount of the organic $\mathrm{C}$ added to the culture, with no net decrease of the seasonally accumulated DOC. These results indicate that the seasonally accumulated DOC could not be metabolized by the surface bacterioplankton assemblage on the time-scale of these experiments. Follow-up experiments that used a combination of HTC and HPLC analysis determined that the carbon removed during the incubations was indeed glucose carbon (Goldberg et al. 2000). These data indicate that although labile carbon was readily utilized, cometabolism, i.e. the use of labile organic matter to gain energy in order to break down more recalcitrant compounds (Madigan et al. 1997), was not a significant process in these 3 treatments.

The production and utilization by in situ biological processes of labile DOM, such as carbohydrates and amino acids, appears to be to be tightly coupled, thus preventing the large-scale accumulation of labile DOM during stratified conditions. The lack of accumulation of labile organic compounds in the northwestern Sargasso Sea summer is evident from the relatively stable DOC stocks observed in the upper $40 \mathrm{~m}$ (Fig. 2) (Hansell \& Carlson 2001). Suttle et al. (1991) demonstrated that microbial utilization of dissolved free amino acids (DFAA) prevented DFAA accumulation and that rapid recycling helped support simultaneous bacterial production in the Sargasso Sea. Pakulski \& Benner (1994) noted that concentrations of bioavailable carbohydrates were lowest in the Sargasso Sea compared to sites in the North Pacific and the Gulf of Mexico. Dissolved free neutral sugar concentrations are also maintained at levels less than $5 \mathrm{nM}$ in the northwestern Sargasso Sea (Carlson \& Otero unpubl. data). These studies demonstrate the rapid utilization of bioavailable substrates. The results of our experiments suggest that the DOC accumulating in the BATS surface layer is of a 'semi-labile' quality and is not available for rapid microbial remineralization by surface bacterioplankton assemblages.

\section{Utilization of seasonally accumulated DOC}

The combination of glucose, $\mathrm{NH}_{4}$ and $\mathrm{PO}_{4}(\mathrm{C}+\mathrm{N}+\mathrm{P})$ caused the most significant bacterial response and 
highest rate of DOC utilization of any treatment tested. Similar increases in bacterial biomass response to the $\mathrm{C}+\mathrm{N}+\mathrm{P}$ relative to individual organic or inorganic enrichments has been noted elsewhere (Pomeroy et al. 1995, Cotner et al. 1997, Rivkin \& Anderson 1997, Shiah et al. 1998, Thingstad et al. 1998, Church et al. 2000). However, no information regarding DOC utilization or community structure shifts was offered in these studies. In the present study, we found that when cultures were enriched with $\mathrm{C}+\mathrm{N}+\mathrm{P}$, the bacterioplankton utilized the entire labile DOC amendment plus an additional 1 to $5 \mu \mathrm{M}$ of the 'semi-labile' DOC during the incubation period. In addition to the increased bacterial production and DOC utilization, clear shifts in bacterioplankton community structure were observed (Fig. 7, Table 3). These results suggest that the utilization of 'semi-labile' DOC in the $\mathrm{C}+\mathrm{N}+\mathrm{P}$ treatments was a function of cometabolism, the development of a specialized microbial community, or a combination of the two.

\section{Community structure, nutrient enrichments and utilization of seasonally accumulated DOC}

LH-PCR is a useful tool to display microbial diversity. This method exploits the fact that length polymorphisms distinguish 16S rDNA in different phylogenetic clusters. The resulting electropherograms (Figs. 6 \& 7) are essentially chromatograms of 'bacterial diversity' (Suzuki 1997, Suzuki et al. 1998). The method measures relative gene frequencies, offers information on the shifts in community structure over time and treatment, and is insensitive to growth rate (Suzuki et al. 1998). In the present study, we used the display of electropherograms to demonstrate whether or not the overall community structure varied as a function of confinement, time, and nutrient enrichment. Specifics about the identity of individual peaks presented here will be discussed in detail elsewhere (Giovannoni et al. unpubl. data).

The data show that bacterial assemblages confined in seawater cultures were similar to the community structure typically observed within the surface $10 \mathrm{~m}$ at BATS during the spring and remained relatively stable for several days in the control, $\mathrm{N}$ and $\mathrm{P}$ treatments (Figs. $6 \&$ 7). The electropherograms show that, in the absence of added glucose plus inorganic macronutrients, a relatively heterogeneous microbial population was maintained over the course of the experiment (Fig. 7, Table 3). The electropherograms prove that there were dramatic shifts in microbial community structure when glucose was added in combination with inorganic nutrients to the cultures. The change in bacterial abundance for the control and inorganic nutrient treatments was minor, compared to labile organic amendments.

The microbial community structure in the control treatments, or when $\mathrm{N}, \mathrm{P}$ or $\mathrm{N}+\mathrm{P}$ were added remained relatively stable for several days compared to the dramatic and rapid shift in community structure when glucose was added with inorganic nutrients. However, some restructuring of the microbial assemblage in the control, and inorganic treatments was evident as changes in the relative areas of some minor peaks. Change in cell abundance within these treatments was minor compared to treatments where labile organic $\mathrm{C}$ was added. Because the electropherograms display relative changes in community structure, the fact that overall change in cell abundance was small indicates the possibility that the biomass was redistributed among some of the minor constituents present at time zero. The conclusion that the microbial community can remain relatively stable for several days is supported by data from gene cloning and sequencing (K. Vergin unpubl. data) but differs from conclusions reached in other studies, which have reported considerable instability and rapid shifts in bacterial community upon confinement. Fuchs et al. (2000) reported that, within $24 \mathrm{~h}$, community structure and microbial biomass changed significantly in seawater culture experiments using coastal seawater. Changes in the availability of labile organic matter and inorganic nutrients in their study may have produced bottom-up controls on community structure and biomass production. Lebaron et al. (1999) and Massana et al. (2001) also reported significant shifts in bacterial community structure upon confinement in Mediterranean Sea mesocosm experiments and Antarctic Polar Front seawater cultures, respectively. It was speculated that a combination of bottom-up and top-down controls was responsible for the observed change in community structure. The experimental results presented in these studies show a shift in community structure to a few opportunistic bacteria strains upon confinement in seawater cultures. Our control culture data, however, indicate that simply confining oligotrophic Sargasso Sea water in unamended dilution cultures does not necessarily lead to domination or rapid growth of 1 or 2 opportunistic strains.

The $\mathrm{C}+\mathrm{N}+\mathrm{P}$ treatments reduced the original heterogeneity of the bacterial assemblage to 2 dominant peaks at the 341 and 361 bp position. Because LHPCR displays the relative contribution of species present, the absence of the amplicons found in the 314 to 319 bp positions at Day 2 and Day 6.7 (Fig. 7F) is likely due to overwhelming production of the species occupying positions 341 and $361 \mathrm{bp}$ rather than the removal of bacterioplankton species in the 314 to 319 bp positions. We cannot rule out the possibility 
that several species occupied the same peak, because many discrete fragment lengths can be shared by multiple species (Suzuki et al. 1998; see their Table 1). However, subsequent studies conducted with Sargasso Sea seawater cultures and fluorescent oligonucleotide probes have shown that the gammaproteobacteria Alteromonas macleodii and Vibrio sp. dominated bacterial biomass in later time points in $\mathrm{C}+\mathrm{N}+\mathrm{P}$ treatments (Carlson unpubl. data). Preliminary results from fluorescent in situ hybridization probes also indicate that $A$. macleodii are present in low numbers within the mesopelagic zone at BATS (Carlson unpubl. data). These culturable gamma-proteobacteria species were also isolated from $\mathrm{C}+\mathrm{N}+\mathrm{P}$ experiments conducted in the northwestern Sargasso Sea (Lanoil et al. 2000). Lebaron et al. (1999) and Fuchs et al. (2000) reported shifts to rapid growing gamma-proteobacteria species in mesocosm and dilution experiments conducted in coastal waters of the Mediterranean Sea and the English Channel, respectively. Fuchs et al. (2000) suggest that because of dramatic shifts in bacterial community structure, enrichment cultures are not accurate indexes for in situ growth of bacterioplankton. However, we suggest that enrichment studies do provide insight into potential controls of biogeochemically significant processes. Cottrell \& Kirchman (2000) demonstrated that uptake rates of various low molecular weight DOM compounds varied considerably among marine proteobacteria groups. While the resulting community structure in the $\mathrm{C}+\mathrm{N}+\mathrm{P}$ treatments may differ from those observed in situ, the coincident remineralization of 'semi-labile' DOC points to the possibility that both nutrient regime and community structure may affect DOC cycling in situ at BATS.

\section{Conclusions}

Field observations show a regular annual pattern of DOC accumulation and export at BATS. A portion of the exported DOC is remineralized below the euphotic zone (Carlson et al. 1994, Hansell \& Carlson 2001). The experiments presented here indicate that the surface bacterioplankton assemblage were incapable of rapid remineralization of the seasonally accumulated surface DOC found in the vicinity of the BATS site. This 'semilabile' DOC did not support rapid bacterioplankton production, and the addition of $\mathrm{N}$ and $\mathrm{P}$ did not increase DOC availability to surface water bacterioplankton. We hypothesize that the composition of the seasonally accumulated DOC at BATS is of a recalcitrant nature and is not readily available to surface water bacterioplankton assemblages. We further hypothesize that under stratified conditions, tight cou- pling between the labile DOC production and microbial consumption supports the instantaneous bacterioplankton production measured in the surface waters at BATS (Carlson et al. 1996, Steinberg et al. 2001) and prevents further accumulation of labile DOC in the euphotic zone. Studies that found bacterioplankton limited by the supply of labile organic matter (Kirchman 1990, Kirchman et al. 1990, Chin-Leo \& Benner 1992, Carlson \& Ducklow 1996, Cherrier et al. 1996, Church et al. 2000, Williams 2000) have shown that the 'malfunctioning microbial loop' is not a ubiquitous phenomenon. However, in most of those studies and the present study, nutrient amendments such as $\mathrm{Fe}$ (Pakulski et al. 1996, Church et al. 2000), NO 3 , Mo, or vitamins were not tested, thus the limitation of bacterial production by these elements cannot be ruled out. Note, though, that our experiments were not fully trace metal clean.

During convective overturn DOC is exported vertically and introduced into a set of physical, chemical, and biological conditions that allow a portion of the 'semi-labile' DOC to be utilized. Giovannoni and colleagues have found that the aphotic zone species are more phylogenetically diverse than observed in the euphotic zone (Giovannoni et al. 1996, Gordon \& Giovannoni 1996, Field et al. 1997). The experiments presented here indicate that the combination of organic and inorganic nutrients, albeit unnatural, can create a condition whereby the bacterioplankton assemblage is able to utilize 'semi-labile' DOC. We do not propose that the species that grew up in our seawater culture are necessarily those responsible for the observed mesopelagic remineralization; however, we do hypothesize that vertical gradients in the availability of nutrients and energy are responsible for diversification and specialization of microbial communities. These specialized microbial communities may, in part, regulate consumption of 'semi-labile' DOC at BATS. Further experimental work is necessary to gain insight and to quantify potential linkages between specialized microbial assemblages and biogeochemical processes, such as utilization of 'semi-labile' DOC within the mesopelagic ocean.

Acknowledgements. We thank the officers and crew of the RV 'Weatherbird II' for their valuable assistance and support Drs. M. Conte and T. Church and BATS chief scientists S. Bell, J. Mitchell and R. Johnson for assisting in water collection and accommodating wire time requests, and C. Van Hilst for assistance with graphics. This manuscript benefited greatly from reviews and discussions with J. Christian, H. Ducklow, K. Gray, J. Oliver and one anonymous reviewer. This work was supported by National Science Foundation grant OCE961922, OCE-9801950, OCE-9977399 and MCB-9977918 to C.A.C; OCE-9618530 and MCB-9977930 to S.J.G; and OCE9726091 to D.A.H. This is BBSR contribution 1626. 


\section{LITERATURE CITED}

Aluwihare LI, Repeta DJ, Chen RF (1997) A major biopolymeric component to dissolved organic carbon in surface seawater. Nature 387:166-169

Ammerman, JW, Fuhrman JA, Hagström Å, Azam F(1984) Bacterioplankton growth in seawater: I. Growth kinetics and cellular characteristics in seawater cultures. Mar Ecol Prog Ser 18:31-39

Amon RMW, Benner R (1994) Rapid cycling of high-molecular-weight dissolved organic matter in the ocean. Nature 369:549-552

Anderson TR, Williams PJleB (1999) A one-dimensional model of dissolved organic carbon cycling in the water column incorporating combined biological-photochemical decomposition. Global Biogeochem Cycles 13(2):337-349

Azam F, Fenchel T, Field JG, Gray JS, Meyer-Reil LA, Thingstad F (1983) The ecological role of water-column microbes in the sea. Mar. Ecol Prog Ser 10:257-263

Azam F, Hodson RE (1977) Size distribution and activity of marine microheterotrophs. Limnol Oceanogr 22:492-501

Barber RT (1968) Dissolved organic carbon from deep water resists microbial oxidation. Nature 220:274-275

Baxter M, Sieburth JM (1984) Metabolic and ultrastructural response to glucose of two eurytrophic bacteria isolated from seawater at different enriching concentrations. Appl Environ Microbiol 47(1):31-38

Benner R, Biddanda B (1998) Photochemical transformation of surface and deep marine dissolved organic matter: effects on bacterial growth. Limnol Oceanogr 43:1373-1378

Benner R, Strom M (1993) A critical evaluation of the analytical blank associated with DOC measurements by hightemperature catalytic oxidation. Mar Chem 41:153-160

Billen G, Fontigny A (1987) Dynamics of a Phaeocystis-dominated spring bloom in Belgian coastal waters. II. Bacterioplankton dynamics. Mar Ecol Prog Ser 37:249-257

Børsheim KY, Myklestad SM (1997) Dynamics of DOC in the Norwegian Sea inferred from monthly profiles collected during 3 years at $66^{\circ} \mathrm{N}, 2^{\circ} \mathrm{E}$. Deep-Sea Res I 44(4): 593-601

Brophy JE, Carlson DJ (1989) Production of biologically refractory dissolved organic carbon by natural seawater microbial populations. Deep-Sea Res 36(4):497-507

Burney CM (1986) Bacterial utilization of total in situ dissolved carbohydrate in offshore waters. Limnol Oceanogr 31:427-431

Carlson CA (2002) Production and removal processes. In: Hansell DA, Carlson CA (eds) Biogeochemistry of marine dissolved organic matter. Academic Press, San Diego, p 91-151

Carlson CA, Bates NR, Ducklow HW, Hansell DA (1999) Estimation of bacterial respiration and growth efficiency in the Ross Sea, Antarctica. Aquat Microb Ecol 19:229-244

Carlson CA, Ducklow HW (1995) Dissolved organic carbon in the upper ocean of the central Equatorial Pacific, 1992: Daily and finescale vertical variations. Deep-Sea Res II 42: 639-656

Carlson CA, Ducklow HW (1996) Growth of bacterioplankton and consumption of dissolved organic carbon in the Sargasso Sea. Aquat Microb Ecol 10:69-85

Carlson CA, Ducklow HW, Sleeteer TD (1996) Stocks and dynamics of bacterioplankton in the Northwestern Sargasso Sea. Deep-Sea Res II 43:491-575

Carlson CA, Ducklow HW, Hansell DA, Smith WO (1998) Organic carbon partitioning during spring phytoplankton blooms in the Ross Sea Polynya and the Sargasso Sea. Limnol Oceanogr 43:375-386
Carlson CA, Ducklow HW, Michaels AF (1994) Annual flux of dissolved organic carbon from the euphotic zone in the Northwestern Sargasso Sea. Nature 371:405-408

Carlson CA, Hansell DA, Peltzer ET, Smith WO (2000) Stocks and dynamics of dissolved and particulate organic matter in the southern Ross Sea, Antarctica. Deep-Sea Res II 47: 3201-3225

Caron DA, Lin EL, Sanders RW, Dennett MR, Berniger UG (2000) Response of bacterioplankton and phytoplankton to organic carbon and inorganic nutrient additions in contrasting oceanic ecosystems. Aquat Microb Ecol 22: $175-184$

Cherrier J, Bauer JE, Druffel ERM (1996) Utilization and turnover of labile dissolved organic matter by bacterial heterotrophs in eastern North Pacific surface waters. Mar Ecol Prog Ser 139:267-279

Chin-Leo G, Benner R (1992) Enhanced bacterioplankton production and respiration at intermediate salinities in the Mississippi River plume. Mar Ecol Prog Ser 87:87-103

Chin-Leo G, Kirchman DL (1990) Unbalanced growth in natural assemblages of marine bacterioplankton. Mar Ecol Prog Ser 63:1-8

Church MJ, Ducklow HW, Karl DM (2002) Multi-year increases in dissolved organic matter inventories at Station ALOHA in the North Pacific Subtropical Gyre. Limnol Oceanogr 47:1-10

Church MJ, Hutchins DA, Ducklow HW (2000) Limitation of bacterial growth by dissolved organic matter and iron in the Southern Ocean. Appl Environ Microbiol 66(2): 455-466

Copin-Montégut G, Avril B (1993) Vertical distribution and temporal variation of dissolved organic carbon in the North-Western Mediterranean Sea. Deep-Sea Res 40(10): 1963-1972

Cotner JB, Ammerman JW, Peele ER, Bentzen E (1997) Phosphorus-limited bacterioplankton growth in the Sargasso Sea. Aquat Microb Ecol 13:141-149

Cottrell MT, Kirchman DL (2000) Natural assemblages of marine proteobacteria and members of the CytophagaFlavobacter cluster consuming low and high molecular weight dissolved organic matter. Appl Environ Microbiol 66(4):1692-1697

del Giorgio PA, Cole JJ (2000) Bacterial energetics and growth efficiency. In: Kirchman DL (ed) Microbial ecology of the oceans. Wiley-Liss, New York, p 289-325

Donachie SP, Christian JR, Karl DM (2001) Nutrient regulation of bacterial production and ectoenzyme activities in the subtropical North Pacific Ocean. Deep-Sea Res II 48(8-9):1719-1732

Ducklow HW, Carlson CA, Bates NR, Knap AH, Michaels AF (1995) Dissolved organic carbon as a component of the biological pump in the North Atlantic Ocean. Phil Trans R Soc Sci Ser A 348:161-167

Ducklow HW, Dickson ML, Kirchman DL, Steward G, Ochardo J, Marra J, Azam F (2000) Constraining bacterial production conversion efficiency and respiration in the Ross Sea, Antarctica, January-February, 1997. Deep-Sea Res II 47:3227-3248

Ducklow HW, Kirchman DL, Quinby HL (1992) Bacterioplankton cell growth and macromolecular synthesis in seawater cultures during the North Atlantic Bloom spring phytoplankton bloom, May 1989. Microb Ecol 24:125-144

Duursma EK (1963) The production of dissolved organic matter in the sea, as related to the primary gross production of organic matter. Neth J Sea Res 2(1):85-94

Eberlein K, Leal MT, Hammer KD, Hickel W (1985) Dissolved organic substances during a Phaeocystis pouchetii bloom 
in the German Bight (North Sea). Mar Biol 89:311-316

Field KG, Gordon D, Wright T, Rappé M, Urbach E, Vergin K, Giovannoni SJ (1997) Diversity and depth-specific distribution of SAR 11 cluster rRNA genes from marine planktonic bacteria. Appl Environ Microbiol 63(1):63-70

Fuchs BM, Zubkov MV, Sahm K, Burkill PH, Amann R (2000) Changes in community composition during dilution cultures of marine bacterioplankton as assessed by flow cytometric and molecular biological techniques. Environ Microbiol 2(2):191-201

Fuhrman J (1992) Bacterioplankton roles in cycling of organic matter: the microbial food web. In: Falkowski PG, Woodhead AD (eds) Primary productivity and biogeochemical cycles in the sea. Plenum Press, New York, p 361-383

Giovannoni SJ, DeLong EF, Schmidt TM, Pace NR (1990) Tangential flow filtration and preliminary phylogenetic analysis of marine picoplankton. Appl Environ Microbiol 56:2572-2575

Giovannoni SJ, Rappé MS, Vergin K, Adair N (1996) 16S rRNA genes reveal stratified open ocean bacterioplankton populations related to the green non-sulfur bacteria phylum. Proc Natl Acad Sci USA 93(7979-7984):7979-7984

Goldberg SJ, Carlson CA, Steinberg DK, Wheeler BR (2000) Bacterioplankton utilization of zooplankton derived DOM and differential utilization of neutral sugars. EOS 80(49): 49

Goldman JC, Hansell DA, Dennett MR (1992) Chemical characterization of three large oceanic diatoms: potential impact on water column chemistry. Mar Ecol Prog Ser 88: 257-270

Gordon D, Giovannoni SJ (1996) Detection of stratified microbial populations related to Chlorobium and Fibrobacter species in the Atlantic and Pacific oceans. Appl Environ Microbiol 62(4):1171-1177

Hansell DA, Carlson CA (1998a) Deep ocean gradients in dissolved organic carbon concentrations. Nature 395: 263-266

Hansell DA, Carlson CA (1998b) Net community production of dissolved organic carbon. Global Biogeochem Cycles 12:443-453

Hansell DA, Carlson CA (2001) Biogeochemistry of total organic carbon and nitrogen in the Sargasso Sea: control by convective overturn. Deep-Sea Res II 48:1649-1667

Hansell DA, Carlson CA, Suzuki S (2002) Dissolved organic carbon export with North Pacific Intermediate Water formation. Global Biogeochem Cycles 16:77-84

Hansell DA, Waterhouse TY (1997) Controls on the meridional distribution of total organic carbon and nitrogen in the eastern South Pacific Ocean. Deep-Sea Res I 44: 843-857

Harvey GR, Boran DA, Chesal LA, Tokar JM (1983) The structure of marine fulvic and humic acids. Mar Chem 12: $119-132$

Hobbie JE, Daley RJ, Jasper S (1977) Use of Nuclepore filters for counting bacteria by epifluorescence microscopy. Appl Environ Microbiol 33:1225-1228

Karner MB, Delong EF, Karl DM (2001) Archaeal dominance in the mesopelagic zone. Nature 409:507-510

Keil RG, Kirchman DL (1994) Abiotic transformation of labile protein to refractory protein in sea water. Mar Chem 45: 187-196

Kirchman D, Ducklow H, Mitchell R (1982) Estimates of bacterial growth from changes in uptake rates and biomass. Appl Environ Microbiol 44(6):1296-1307

Kirchman D, Keil R, Wheeler PA (1990) Carbon limitation of ammonium uptake by heterotrophic bacteria in the subarctic Pacific. Limnol Oceanogr 35(6):1267-1278
Kirchman DL (1990) Limitation of bacterial growth by dissolved organic matter in the subarctic Pacific. Mar Ecol Prog Ser 62:47-54

Kirchman DL, Lancelot C, Fasham M, Legendre L, Radach G, Scott M (1993) Dissolved organic matter in biogeochemical models of the ocean. In: Evans GT, Fasham MJR (eds) Towards a model of ocean biogeochemical processes. Springer-Verlag, Berlin, p 209-225

Kirchman DL, Suzuki Y, Garside C, Ducklow HW (1991) High turnover rates of dissolved organic carbon during a spring phytoplankton bloom. Nature 352:612-614

Kroer N (1993) Bacterial growth efficiency on natural dissolved organic matter. Limnol Oceanogr 38(6):1282-1290

Lampert W (1978) Release of dissolved organic carbon by grazing zooplankton. Limnol Oceanogr 23(4):831-834

Lancelot C (1979) Gross excretion rates of natural marine phytoplankton and heterotrophic uptake of excreted products in the southern North Sea, as determined by short-term kinetics. Mar Ecol Prog Ser 1:179-186

Lanoil B, Carlson CA, Giovanonni SJ (2000) Bacterial chromosomal painting for in situ monitoring of cultured marine bacteria. Environ Microbiol 2:654-665

Lebaron P, Servais P, Troussellier M, Courties C and 6 others (1999) Changes in bacterial community structure in seawater mesocosm differing in their nutrient status. Aquat Microb Ecol 19:255-267

Legendre L, Le Fevre J (1995) Microbial food webs and the export of biogenic carbon in oceans. Aquat Microb Ecol 9: 69-77

Madigan MT, Martinko JM, Parker J (1997) Brock biology of microorganisms, eighth edition. Prentice-Hall, Upper Saddle River, NJ

Massana R, Pedrós-Alió C, Casamayor EO, Gasol JM (2001) Changes in marine bacterioplankton phylogenetic composition during incubations designed to measure biogeochemically significant parameters. Limnol Oceanogr 46(5): $1118-1188$

McCarthy MD, Hedges JI, Benner R (1998) Major bacterial contribution to marine dissolved organic nitrogen. Science 281:231-234

McGillicuddy DJ, Robinson AR (1997) Eddy-induced nutrient supply and new production in the Sargasso Sea. Deep-Sea Res I 44(8):1427-1450

McGillicuddy DJ, Robinson AR, Siegel DA, Jannasch HW and 5 others (1998) Influence of mesoscale eddies on new production in the Sargasso Sea. Nature 394:263-265

Michaels AF, Knap AH (1996) Overview of theUS. JGOFS Bermuda Atlantic Time-series Study and Hydrostation S program. Deep-Sea Res II 43(2-3):157-198

Nagata T, Kirchman DL (1996) Bacterial degradation of protein adsorbed to model submicron particles in seawater. Mar Ecol Prog Ser 132:241-248

Nagata T, Kirchman DL (1992) Release of dissolved organic matter by heterotrophic protozoa: implications for microbial foodwebs. Arch Hydrobiol 35:99-109

Ogura N (1972) Rate and extent of decomposition of dissolved organic matter in the surface water. Mar Biol 13:89-93

Pakulski JD, Benner R (1994) Abundance and distribution of carbohydrates in the ocean. Limnol Oceanogr 39(4): 930-940

Pakulski JD, Coffin RB, Kelley CA, Holder SL, Downer R, Aas P, Lyons MM, Jeffrey WH (1996) Iron stimulation of Antarctic bacteria. Nature 383:133-134

Parsons TR, LeBrasseur RJ, Barraclough WE (1970) Levels of production in the pelagic environment of the Strait of Georgia, British Columbia: a review. J Fish Res Board Can 27(7):1251-1264 
Pomeroy LR (1974) The ocean's food web, a changing paradigm. BioScience 24:499-504

Pomeroy LR, Deibel D (1986) Temperature regulation of bacterial activity during the spring bloom in Newfoundland coastal waters. Science 233:359-361

Pomeroy LR, Wiebe WJ, Deibel D, Thompson RJ, Rowe GR, Pakulski JD (1991) Bacterial response to temperature and substrate concentrations during the Newfoundland spring bloom. Mar Ecol Prog Ser 75:143-159

Pomeroy LR, Sheldon JE, Sheldon WM, Peters F (1995) Limits to growth and respiration of bacterioplankton in the Gulf of Mexico. Mar Ecol Prog Ser 117:259-268

Porter KG, Feig YS (1980) The use of DAPI for identification and counting aquatic microflora. Limnol Oceanogr 25: 943-948

Proctor LM, Fuhrman JA (1991) Roles of viral infection in organic particle flux. Mar Ecol Prog Ser 69:133-142

Rich JH, Ducklow HW, Kirchman DL (1996) Concentration and uptake of neutral monosaccharides along $140^{\circ} \mathrm{W}$ in the equatorial Pacific: contribution of glucose to heterotrophic bacterial activity and the DOM flux. Limnol Oceanogr 41(4):595-604

Rivkin RB, Anderson MR (1997) Inorganic nutrient limitation of oceanic bacterioplankton. Limnol Oceanogr 42:730-740

Shiah FK, Ducklow HW (1994) Temperature regulation of heterotrophic bacterioplankton abundance, production, and specific growth rate in Chesapeake Bay. Limnol Oceanogr 39(6):1243-1258

Shiah FK, Kao SJ, Liu KK (1998) Bacterial production in the Western Equatorial Pacific: implications of inorganic nutrient effects on dissolved organic carbon accumulation and consumption. Bull Mar Sci 62(3):795-808

Smith D, Simon M, Alldredge AL, Azam F (1992) Intense hydrolytic enzyme activity on marine aggregates and implications for rapid particle dissolution. Nature 359: $139-142$

Søndergaard M, Middelboe M (1995) A cross-system analysis of labile dissolved organic carbon. Mar Ecol Prog Ser 118: 283-294

Søndergaard M, Williams PJleB, Cauwet G, Riemann B, Robinson C, Terzic S, Woodward EMS, Worm J (2000) Net accumulation and flux of dissolved organic carbon and dissolved organic nitrogen in marine plankton communities. Limnol Oceanogr 45(5):1097-1111

Sprintall J, Tomczak M (1992) Evidence of the barrier layer in the surface layer of the tropics. J Geophys Res 97: 7305-7316

Steinberg DK, Carlson CA, Bates NR, Johnson RJ, Michaels AF, Knap AH (2001) Overview of the US. JGOFS Bermuda Atlantic Time-series Study (BATS): a decade-scale look at ocean biology and biogeochemistry. Deep-Sea Res II 48: $1405-1447$

Strom SL (2000) Bacterivory interactions between bacteria and their grazers. In: Kirchman DL (ed) Microbial ecology of the ocean. Wiley-Liss, New York, p 351-386

Editorial responsibility: David Karl,

Honolulu, Hawaii, USA
Suttle CA, Chan AM, Fuhrman JA (1991) Dissolved free amino acids in the Sargasso Sea: uptake and respiration rates, turnover times, and concentrations. Mar Ecol Prog Ser 70:189-199

Suzuki M (1997) The effect of protestant bacterivory on bacterioplankton community structure. Microbiology. University of Oregon, Corvallis, OR

Suzuki M, Giovannoni SJ (1996) Bias caused by template annealing in the amplification of 16S rRNA genes by the PCR. Appl Environ Microbiol 62:625-630

Suzuki MT, Rappé MS, Giovannoni SJ (1998) Kinetic bias in estimate of costal picoplankton community structure obtained by measurements of small-subunit rRNA gene PCR amplicon length heterogeneity. Appl Environ Microbiol 63:983-989

Tanoue E, Nishiyama S, Kamo M, Tsugita A (1995) Bacterial membranes: possible source of a major dissolved protein in seawater. Geochim Cosmochim Acta 59(12): 2643-2648

Thingstad TF (1993) Microbial processes and the biological carbon pump. In: Evans GT, Fasham MJR (eds) Towards a model of ocean biogeochemical processes. SpringerVerlag, Berlin, p 193-207

Thingstad TF, Rassoulzadegan F (1995) Nutrient limitation, microbial food webs, and biological C-pumps: suggested interactions in a P-limited Mediterranean. Mar Ecol Prog Ser 117:299-306

Thingstad TF, Hagström Å, Rassoulzadegan F (1997) Accumulation of degradable DOC in surface waters: is it caused by a malfunctioning microbial loop? Limnol Oceanogr 42(2):398-404

Thingstad TF, Zweifel UL, Rassoulzadegan F (1998) P limitation of heterotrophic bacteria and phytoplankton in the northwest Mediterranean. Limnol Oceanogr 43(1):88-94

Toggweiler JR (1989) Is the downward dissolved organic matter (DOM) flux important in carbon transport? In: Berger WH, Smetacek VS, Wefer G (eds) Productivity of the ocean: present and past. John Wiley, New York, p 65-83

Toolan T, Wehr JD, Findlay S (1991) Inorganic phosphorus stimulation of bacterioplankton production in a mesoeutrophic lake. Appl Environ Microbiol 57(7):2074-2078

Williams PJleB (2000) Heterotrophic bacteria and the dynamics of dissolved organic material. In: Kirchman DL (ed) Microbial ecology of the oceans. Wiley-Liss, New York, p 153-200

Wu J, Sunda W, Boyle EA, Karl DM (2000) Phosphate depletion in the Western North Atlantic Ocean. Science 289: $759-762$

Zweifel UL (1999) Factors controlling accumulation of labile dissolved organic carbon in the Gulf of Riga. Estuar Coastl Shelf Sci 48:357-370

Zweifel UL, Norrman B, Hagström ^̊ (1993) Consumption of dissolved organic carbon by marine bacteria and demand for inorganic nutrients. Mar Ecol Prog Ser 101:23-32

Submitted: June 26, 2001; Accepted: October 22, 2002

Proofs received from author(s): November 15, 2002 